\title{
Article \\ Biomimetic Citrate-Coated Luminescent Apatite Nanoplatforms for Diclofenac Delivery in Inflammatory Environments
}

\author{
Sandra Maria Cano Plá ${ }^{1,+}$, Annarita $D^{\prime}$ Urso $^{2,+}$, Jorge Fernando Fernández-Sánchez ${ }^{3} \mathbb{D}$, Donato Colangelo ${ }^{2} \mathbb{D}$, \\ Duane Choquesillo-Lazarte ${ }^{1}\left(\mathbb{D}\right.$, Riccardo Ferracini ${ }^{4,5}$ (D), Michela Bosetti ${ }^{6}$ (D), Maria Prat $2,7,8,9, *(\mathbb{D})$ \\ and Jaime Gómez-Morales ${ }^{1, * \mathbb{B}}$
}

check for updates

Citation: Cano Plá, S.M.; D’Urso, A.; Fernández-Sánchez, J.F.; Colangelo,

D.; Choquesillo-Lazarte, D.; Ferracini, R.; Bosetti, M.; Prat, M.; Gómez-

Morales, J. Biomimetic CitrateCoated Luminescent Apatite Nanoplatforms for Diclofenac Delivery in Inflammatory Environments. Nanomaterials 2022, 12, 562. https://doi.org/10.3390/ nano12030562

Academic Editors: Marcin Runowski and Stefano Leporatti

Received: 31 December 2021

Accepted: 2 February 2022

Published: 6 February 2022

Publisher's Note: MDPI stays neutral with regard to jurisdictional claims in published maps and institutional affiliations.

Copyright: () 2022 by the authors. Licensee MDPI, Basel, Switzerland. This article is an open access article distributed under the terms and conditions of the Creative Commons Attribution (CC BY) license (https:// creativecommons.org/licenses/by/ $4.0 /)$.
1 Laboratorio de Estudios Cristalográficos, IACT, CSIC-UGR, Avda. Las Palmeras, n 4, E-18100 Granada, Spain; sandra@lec.csic.es (S.M.C.P.); duane.choquesillo@csic.es (D.C.-L.)

2 Dipartimento di Scienze della Salute, Università del Piemonte Orientale, "A. Avogadro" Via Solaroli, 17, 28100 Novara, Italy; annarita.durso@med.uniupo.it (A.D.); donato.colangelo@med.uniupo.it (D.C.)

3 Department of Analytical Chemistry, Faculty of Sciences, University of Granada, Avda. Fuentenueva s/n, 18071 Granada, Spain; jffernan@ugr.es

4 Dipartimento di Scienze Chirurgiche e Diagnostiche Integrate, Università di Genova, Viale Benedetto XV 6, 16132 Genova, Italy; ferracini@edu.unige.it

5 Ospedale Koelliker, Corso Galileo Ferraris, 247/255, 10134 Torino, Italy

6 Dipartimento di Scienze del Farmaco, Università del Piemonte Orientale "A. Avogadro", Via Bovio 4, 28100 Novara, Italy; michela.bosetti@uniupo.it

7 Centro di Biotecnologie per la Ricerca Medica Applicata (BRMA), Via Solaroli 17, 28100 Novara, Italy

8 Consorzio Interuniversitario per Biotecnologie (CIB), Località Padriciano 99, 34149 Area di Ricerca, Italy

9 Consorzio Interuniversitario Nazionale per la Scienza e Tecnologia dei Materiali (INSTM), Via Giuseppe Giusti, 9, 50121 Firenze, Italy

* Correspondence: maria.prat@med.uniupo.it (M.P.); jaime@lec.csic.es (J.G.-M.); Tel.: +39-0321660662 (M.P.); +34-958525020 (J.G.-M.)

+ These authors contributed equally to this work.

Abstract: Luminescent nanoparticles are innovative tools for medicine, allowing the imaging of cells and tissues, and, at the same time, carrying and releasing different types of molecules. We explored and compared the loading/release ability of diclofenac (COX-2 antagonist), in both undoped- and luminescent Terbium ${ }^{3+}\left(\mathrm{Tb}^{3+}\right)$-doped citrate-coated carbonated apatite nanoparticles at different temperatures $\left(25,37,40^{\circ} \mathrm{C}\right)$ and $\mathrm{pHs}(7.4,5.2)$. The cytocompatibility was evaluated on two osteosarcoma cell lines and primary human osteoblasts. Biological effects of diclofenac-loaded-nanoparticles were monitored in an in vitro osteoblast's cytokine-induced inflammation model by evaluating COX-2 mRNA expression and production of $\mathrm{PGE}_{2}$. Adsorption isotherms fitted the multilayer Langmuir-Freundlich model. The maximum adsorbed amounts at $37^{\circ} \mathrm{C}$ were higher than at $25^{\circ} \mathrm{C}$, and particularly when using the $\mathrm{Tb}^{3+}$-doped particles. Diclofenac-release efficiencies were higher at $\mathrm{pH}$ 5.2, a condition simulating a local inflammation. The luminescence properties of diclofenacloaded $\mathrm{Tb}^{3+}$-doped particles were affected by $\mathrm{pH}$, being the relative luminescence intensity higher at pH 5.2 and the luminescence lifetime higher at $\mathrm{pH} 7.4$, but not influenced either by the temperature or by the diclofenac-loaded amount. Both undoped and $\mathrm{Tb}^{3+}$-doped nanoparticles were cytocompatible. In addition, diclofenac release increased COX-2 mRNA expression and decreased $\mathrm{PGE}_{2}$ production in an in vitro inflammation model. These findings evidence the potential of these nanoparticles for osteo-localized delivery of anti-inflammatory drugs and the possibility to localize the inflammation, characterized by a decrease in $\mathrm{pH}$, by changes in luminescence.

Keywords: inflammation treatment; diclofenac-loaded nanoparticles; apatite; $\mathrm{Tb}^{3+}$-doped apatite; luminescence; cytocompatibility 


\section{Introduction}

Nanotechnology is finding increasing applications in medicine; in particular nanoparticles (NPs) can be used as vehicles to transport and deliver different classes of biologically active molecules (so-called nanocarriers), including chemotherapeutics, antibiotics, antiinflammatory drugs, hormones, fluorophores, targeting agents [1-7], depending on the pathology considered, acting both in diagnosis and therapy. Their main advantage is linked to their nanoscale dimensions, enabling them to carry high amounts of molecules to chosen body sites, in the meantime protecting the drugs from rapid degradation or clearance. This allows to reduce the dose of the administered drugs, lowering or eliminating their unwanted systemic side effects. From the other side, also the nature/composition of the nanocarrier can vary depending on the diseases to be treated. Today bone tissue pathologies, such as osteoporosis, osteoarthritis and rheumatoid arthritis represent important health problems with considerable socio-economic burden, linked to the general population aging $[8,9]$. These musculo-skeletal disorders are characterized by a clinical condition of inflammation. In osteoporosis osteocatabolic processes prevail during bone remodelling, leading to a decrease of trabecular mass density, increasing the risk of bone fracture with concurrent inflammatory reaction [10]. In osteoarthritis the articular cartilages are consumed exposing the bones in the joint to mechanical stresses, with the development of a painful inflammatory reaction [11], while rheumatoid arthritis is an autoimmune disease characterized by chronic inflammation of synovial tissues, joints and cartilage leading to function loss and joint destruction [12]. For all these pathologies the available therapeutic strategies are still unsatisfactory, namely because of the associated side effects.

In this context, apatite (Ap) NPs, which consist of calcium phosphate and closely mimic bone apatite nanocrystals both from chemical and structural points of view, are particularly suited for therapeutic and diagnostic applications. Bone nanoapatite is nonstoichiometric calcium- (and $\mathrm{OH}-$ ) deficient in respect to the mineral hydroxyapatite [HA, $\left.\mathrm{Ca}_{10}\left(\mathrm{PO}_{4}\right)_{6}(\mathrm{OH})_{2}\right]$, it incorporates substituting ions such as $\mathrm{CO}_{3}{ }^{2-}, \mathrm{Mg}^{2+}, \mathrm{Na}^{+}$and other minor elements in its crystal structure [13], and contains citrate molecules strongly adsorbed on its surface [14]. Synthetic apatite-based materials including injectable calcium phosphates, or natural and synthetic polymer-apatite composites, are being used for bone repair applications exploiting their well-known properties of biodegradability, bioactivity and osteoinductivity, besides the capability of improving bone mechanical properties [15-18]. The apatite surfaces can be modified (charged to improve the interactions with living cells, particularly the osteoblasts) [19]. In addition, Ap NPs have already been shown to be valuable nanocarriers for different types of molecules [20], including nucleic acids [21], proteins [22], antibiotics [3], chemotherapeutics [23,24], fluorophores [25], and luminescent moieties [26,27]. Among their advantageous properties are high biocompatibility, good biodegradability, high loading capacity with the ability to bind moieties through both surface calcium and phosphate groups by isothermal adsorption. Moreover, because of their good stability at physiological $\mathrm{pH}$ with partial solubility at acidic $\mathrm{pH}$ they behave as smart complexes sensitive to local stimuli, e.g., binding drugs at physiological $\mathrm{pH}$ and releasing them at acidic $\mathrm{pH}$ [28], as the one found in inflamed or tumor tissues. Synthetic Ap NPs with $\mathrm{CO}_{3}{ }^{2-}$ substitutions and covered by a certain amount of citrate, makes them even more biomimetic to bone apatite in terms of chemical composition and reactivity [14,29]. Lanthanide elements such as $\mathrm{Eu}^{3+}$ and $\mathrm{Tb}^{3+}$ have been recently employed to prepare luminescent apatite-based nanomaterials for drug release and bioimaging applications [30,31]. They exhibit different fluorescence emission colors (red and green, respectively), long luminescence lifetimes, and good resistance to photobleaching. In addition to these features, $\mathrm{Tb}^{3+}$ was found to have bactericidal activity [32], and to promote adhesion and osteogenic differentiation of mesenchymal stem cells $[33,34]$.

Sodium diclofenac (DF) is a non-steroidal anti-inflammatory drug (NSAID) with analgesic, anti-inflammatory and anti-pyretic activities, exerting its activity by competitively blocking cyclooxygenases-2 (COX-2) enzymatic activity responsible for the synthesis of inflammatory mediators, e.g., prostaglandin $\mathrm{E}_{2}\left(\mathrm{PGE}_{2}\right)[35,36]$. As all the NSAIDs, DF has 
adverse systemic side effects, such as gastrointestinal ulceration and bleeding, hepato-renal dysfunction, disorders in the cardiovascular and central nervous systems, and skin reactions $[37,38]$. Local delivery of this drug via Ap NPs would offer a method of bypassing inconveniences. In addition, the use of $\mathrm{Tb}^{3+}$-doped Ap NPs would allow their localization by luminescence emission. Thus, our aim is to explore the loading/release behavior, luminescence properties, and in vitro biological effects of these NPs in normal physiological conditions and in a condition simulating inflammation.

In particular, herein we produced biomimetic citrate-coated $\mathrm{CO}_{3}-\mathrm{Ap}(\mathrm{cAp})$ and citratecoated $\mathrm{Tb}^{3+}$-doped $\mathrm{CO}_{3}-\mathrm{Ap}(\mathrm{cAp}-\mathrm{Tb}) \mathrm{NPs}$. Next, we studied the adsorption and release of DF at physiological pH $7.4\left(25\right.$ and $\left.37{ }^{\circ} \mathrm{C}\right)$, and release at pHs 7.4 and 5.2 simulating local inflammation, as well as the luminescent properties of DF-loaded cAp-Tb NPs at $\mathrm{pHs}$ 7.4 and 5.2, and at 25,37 and $40^{\circ} \mathrm{C}$. Then, we tested their cytocompatibility on different cell lines of bone origin, as well as on human primary osteoblasts (hOB) and osteoblasts differentiated in vitro from adipose-derived mesenchymal stem cells (differentiated hOB). Finally, we analysed the anti-inflammatory activity of DF-loaded cAp NPs on osteoblasts treated with a mixture of inflammatory cytokines (IL- $1 \beta$, TNF- $\alpha$, IFN- $\gamma$ ) by evaluating COX-2 activity and cellular production of $\mathrm{PGE}_{2}$.

\section{Materials and Methods}

\subsection{Reagents}

Diclofenac sodium salt (2-[(2,6-Dichlorophenyl)amino]benzeneacetic acid sodium salt, $\mathrm{MW}=318.13)$, calcium chloride dihydrate $\left(\mathrm{CaCl}_{2} \cdot 2 \mathrm{H}_{2} \mathrm{O}\right.$, Bioxtra, $\geq 99.0 \%$ pure, $\mathrm{MW}=147.01)$, terbium (III) chloride anhydrous $\left(\mathrm{TbCl}_{3}, 99.9 \%\right.$ pure, trace metals, $\mathrm{MW}=265.28)$, sodium citrate tribasic dihydrate $\left(\mathrm{Na}_{3}(\mathrm{cit}) \cdot 2 \mathrm{H}_{2} \mathrm{O}\right.$, cit $=$ citrate $=\mathrm{C}_{6} \mathrm{H}_{5} \mathrm{O}_{7}$, ACS reagent, $\geq 99.0 \%$ pure; $\mathrm{MW}=294.1)$, and sodium phosphate dibasic $\left(\mathrm{Na}_{2} \mathrm{HPO}_{4}, \mathrm{ACS}\right.$ reagent, $\geq 99.0 \%$ pure, $\mathrm{MW}=141.96$ ) were provided by Sigma-Aldrich (St. Louis, MO, USA), while sodium carbonate monohydrate $\left(\mathrm{Na}_{2} \mathrm{CO}_{3} \cdot \mathrm{H}_{2} \mathrm{O}, \mathrm{ACS}\right.$ reagent, $99.5 \%$ pure, $\mathrm{MW}=124)$ and hydrochloric acid $\left(\mathrm{HCl}\right.$, ACS reagent, $37 \mathrm{wt} \%$ in $\left.\mathrm{H}_{2} \mathrm{O}, \mathrm{MW}=36.46\right)$ were supplied by Merck (Darmstadt, Germany) and Panreac (Barcelona, Spain), respectively. The solutions were prepared with Milli-Q water (deionized $0.22 \mu \mathrm{S}, 25^{\circ} \mathrm{C}$, Millipore, Burlington, MA, USA).

\subsection{Preparation of $c A p$ and $c A p-T b$ Nanoparticles}

Nanoparticles of cAp were prepared by the method of thermal decomplexing of $\mathrm{Ca}^{2+} / \mathrm{cit} /$ phosphate/carbonate solutions [29]. A solution of composition $0.06 \mathrm{M} \mathrm{Na}_{2} \mathrm{HPO}_{4}$ $+0.1 \mathrm{M} \mathrm{Na}_{2} \mathrm{CO}_{3}(50 \mathrm{~mL})$ was mixed with a solution of composition $0.1 \mathrm{M} \mathrm{CaCl}_{2}+0.2 \mathrm{M}$ $\mathrm{Na}_{3}$ (cit) $(50 \mathrm{~mL})$ at $4{ }^{\circ} \mathrm{C}$ in a Pyrex glass bottle, and the $\mathrm{pH}$ adjusted to 8.5 with diluted $\mathrm{HCl}$. The bottle was immediately introduced in a water bath at $80^{\circ} \mathrm{C}$ and then in anen at the same temperature for $96 \mathrm{~h}$. For the preparation of $\mathrm{cAp}-\mathrm{Tb}$ nanoparticles the second solution was composed of $0.010 \mathrm{M} \mathrm{Tb}^{3+}+0.09 \mathrm{M} \mathrm{CaCl}_{2}+0.2 \mathrm{M} \mathrm{Na}_{3}$ (cit). This experiment lasted $4 \mathrm{~h}$. Both precipitates were washed 4 consecutive times by centrifugation $(9000 \mathrm{rpm}$, 30 min each) using Milli-Q water and dried in an oven with circulating forced air at $37.5^{\circ} \mathrm{C}$ for 4 days.

\subsection{Characterization of the Nanoparticles}

The nanoparticles were characterized by X-ray diffraction (XRD) using a Bruker D8 Advance Vario Serie II (Bruker AXS, (Bruker GmbH, Karlsruhe, Germany) using $\mathrm{CuK} \alpha$ radiation (1.5406 $\AA$ ). Fourier Transform Infrared Spectrum (FTIR) was recorded with a Perkin-Elmer Spectrum One FTIR (Perkin Elmer, Shelton, WA, USA) in the wavenumber range from $4000 \mathrm{~cm}^{-1}$ a $400 \mathrm{~cm}^{-1}$. Plates were prepared with a concentration of $\sim 1 \mathrm{wt} \%$ in anhydrous $\mathrm{KBr}(\mathrm{MW}=119)$ and then pressed with a hydraulic pump to 10 tons. Raman spectrum were recorded with a LabRAMHR spectrometer (Jobin-Yvon, Horiba, Tokyo, Japan) provided of a laser diode that emits at a wavelength of $532 \mathrm{~nm}$. Transmission electron microscopy images (TEM) were taken with a Libra 120 Plus TEM instrument 
(EELS) at $80 \mathrm{kV}$ (Carl Zeiss, Jena, Germany). Prior observation, the samples were dispersed in absolute ethanol $(\geq 99.8 \% v / v)$ and deposited on copper microgrids coated with film of FORMVAR carbon. The particle size distribution (PSD) and $\zeta$-potential were analysed by dynamic light scattering (DLS) with a Zetasizer Nano ZS analyser (Malvern Instruments Ltd., Malvern, UK) in aqueous suspensions $(\sim 0.5 \mathrm{mg} / \mathrm{mL}$, room temperature $)$ contained in polystyrene vials. For measurements of $\zeta$-potential versus $\mathrm{pH}$, suspensions of the nanoparticles were prepared at $\mathrm{pHs}$ from 4 to 9 using the MPT2 autotitrator with dilute $\mathrm{HCl}$ and $\mathrm{NaOH}$ (MW 39.997) solutions (0.25 and 0.1 M, respectively). Elemental analysis of $\mathrm{Tb}^{3+}$ was carried out by inductively coupled plasma mass spectroscopy (ICP-MS) using a Perkin Elmer NexION 300D ICP Mass spectrometer (Perkin Elmer, Beaconsfield, UK). C and $\mathrm{H}$ were determined by thermoanalysis using Thermo Scientific ${ }^{\mathrm{TM}}$ FLASH 2000 CHNS/O Analyzer of Thermo Fisher Scientific (Waltham, MA, USA).

\subsection{Adsorption Kinetics}

For adsorption kinetic studies we prepared 7 eppendorf tubes containing $2 \mathrm{mg}$ of adsorbent (cAp and cAp-Tb) in $1 \mathrm{~mL}$ of phosphate buffered saline (PBS) solution containing $\mathrm{DF}$ at the maximum solubility $(0.45 \mathrm{mg} / \mathrm{mL})$. The PBS buffer $(\mathrm{pH}=7.4)$ was prepared with the following composition: $137 \mathrm{mM} \mathrm{NaCl}(\mathrm{MW}=58.44), 2.7 \mathrm{mM} \mathrm{KCl}(\mathrm{MW}=74.55), 10 \mathrm{mM}$ $\mathrm{Na}_{2} \mathrm{HPO}_{4}$ and $1.8 \mathrm{mM} \mathrm{KH}_{2} \mathrm{PO}_{4}(\mathrm{MW}=136.08)$. The tubes were left in the dark each one for a different time: $1 \mathrm{~h}, 2 \mathrm{~h}, 4 \mathrm{~h}, 8 \mathrm{~h}, 15 \mathrm{~h}, 24 \mathrm{~h}$ and $48 \mathrm{~h}$. At the end of the experiment, the solid was decanted by centrifugation at 10,000 rpm for $5 \mathrm{~min}$. The absorbance of the residual solution was then measured with an UV-Vis (Agilent Technologies Cary Series UV-Vis, Agilent Technologies, Madrid, Spain) Spectrophotometer at $\lambda=280 \mathrm{~nm}$ [39] and the amount of DF adsorbed per unit mass of adsorbent as a function of time determined. The DF concentration $C_{D F}$ was determined from the calibration straight line whose equation is the following:

$$
A b s=32.267 C_{D F}+0.02
$$

\subsection{Adsorption Isotherms}

Experiments were carried out in several Eppendorf tubes containing $2 \mathrm{mg}$ of adsorbent (cAp and cAp- Tb) in $1 \mathrm{~mL}$ of PBS solution with varying concentrations of DF $(0.05,0.1$, $0.15,0.20,0.25,0.30,0.35,0.40$ and $0.45 \mathrm{mg} / \mathrm{mL})$. The trials were carried out in triplicate under continuous stirring at 25 and $37^{\circ} \mathrm{C}$ for $24 \mathrm{~h}$ (time higher than that necessary to reach the adsorption equilibrium according to adsorption kinetics). At the end, samples were centrifuged at 10,000 rpm for $5 \mathrm{~min}$, and then filtered. The equilibrium concentration $\left(C_{e q}\right.$, $\mathrm{mg} / \mathrm{mL}$ ) of DF in the supernatants were analysed by UV-Vis applying Equation (1). The adsorbed amount of DF per unit mass of adsorbent $\left(Q_{a d s}, \mathrm{mg} / \mathrm{mg}\right)$ was then calculated by difference between the initial $\left(C_{0}\right)$ and equilibrium $\left(C_{e q}\right)$ concentrations, divided by the mass (mg) of adsorbent, for a $1 \mathrm{~mL}$ total volume. The plot of $Q_{a d s}$ versus $C_{e}$ is the adsorption isotherm.

\subsection{Release Experiments}

Release experiments at a function of time ( $1 \mathrm{~h}$ to 7 days) were performed at 25 and $37^{\circ} \mathrm{C}$ under agitation using PBS ( $\mathrm{pH} 7.4)$ and citrate/ $\mathrm{NaOH}(\mathrm{pH}=5.2)$ buffers solutions. Each Eppendorf tube contained $2 \mathrm{mg}$ of nanoparticles (DF-cAp and DF-cAp-Tb) with maximum adsorbed DF amount $\left(Q_{\max }\right)$ immersed in $1 \mathrm{~mL}$ buffer solution. At each programmed time, the suspensions were centrifuged at 10,000 rpm for $5 \mathrm{~min}$, filtered, and the $C_{D F}$ in the supernatant analysed by UV-Vis. All assays were performed in triplicate and in the dark since the DF is photosensitive.

\subsection{Luminescence Studies of $c A p-T b-D F$ Samples}

Measurements were carried out at 25,37 , and $40{ }^{\circ} \mathrm{C}$, at pHs 5.2 and 7.4 (adjusted with diluted $\mathrm{HCl}$ and $\mathrm{NaOH}$ ), using a $0.5 \mathrm{mg} / \mathrm{mL}$ suspension of $\mathrm{cAp}-\mathrm{Tb}$ sample. The nanoparticles were loaded in $0.0,0.1,0.3$ and $0.4 \mathrm{mg} / \mathrm{mL}$ DF solution for $24 \mathrm{~h}$, as in the 
adsorption experiments. The excitation and emission wavelengths used were $\lambda_{\text {exc }}=350 \mathrm{~nm}$ and $\lambda_{\mathrm{em}}=545 \mathrm{~nm}$. The instrumental parameters for the spectral characterization of the particles in aqueous suspensions were: $t_{d}=120 \mu \mathrm{s}, t_{g}=5 \mathrm{~ms}$, slitswidth $\mathrm{exc}_{\mathrm{em}}=20 / 20 \mathrm{~nm}$ and detector voltage $750 \mathrm{v}$. The instrumental parameters for the lifetime characterization were: $t_{d}=120 \mu s, t_{g}=0.01 \mathrm{~ms}$, slitswidthexc/em $=20 / 20 \mathrm{~nm}$ and detector voltage $900 \mathrm{~V}$.

\subsection{Cells}

The two human osteosarcoma cell lines MG-63 (CRL-1427) and U-2 OS (HTB-96TM), which were obtained from ATTC, were grown in Dulbecco modified Eagle's medium (DMEM) (Sigma-Aldrich, Milan, Italy) supplemented with 10\% foetal bovine serum (FBS), antibiotic solution (streptomycin $100 \mu \mathrm{g} / \mathrm{mL}$ and penicillin $100 \mathrm{U} / \mathrm{mL}$, Sigma-Aldrich) and $2 \mathrm{mM}$ L-glutamine (complete medium) in a humidified atmosphere containing 5\% $\mathrm{CO}_{2}$ at $37^{\circ} \mathrm{C}$. Human primary osteoblasts (hOB) at passages from 2 to 7 obtained from explants of human trabecular bone fragments from knee joints taken at surgery (kindly provided by the Orthopedic Institute, Major Hospital Charity, Novara, Italy) were cultured in Iscove's modified Dulbecco's medium supplemented as above (complete Ob medium), as described previously [40]. Mesenchymal Stem Cells (MSCs) were obtained from the stromal vascular fraction of lipoaspirates, after enzymatic digestion with Collagenase NB4 (SERVA Electrophoresis, GmbH, Heidelberg, Germany) and elimination of blood cells, isolated and characterized as described by Roato [41]. MSCs were induced to osteogenesis by 2 week treatment with (complete Ob medium containing $50 \mathrm{mg} / \mathrm{mL}$ ascorbic acid (MW 176.12), $10 \mathrm{mM} \beta$-glicerophosphate (MW 216.04), and $10 \mathrm{nM}$ dexamethasone (MW 392.5) (all from Sigma-Aldrich), which were changed every 3 days [42]. The osteogenic differentiation was evaluated by staining with an alkaline phosphatase detection kit (Millipore, Merk Millipore, Milano, Italy) according to the manufacturer's protocol (see Supplementary data). These cells were named differentiated hOB. All patients were free of systemic disease or treatment. The samples represent surgical discharge materials, and therefore their use does not need ethics committee approval. All patients were informed about the scientific use of the materials removed and gave their consent.

\subsection{Cytocompatibility Tests}

MG-63 and U-2OS cells (5000 cells/wells in 96-well plates) were seeded and $24 \mathrm{~h}$ after different concentrations (ranging from 0.1 to $100 \mu \mathrm{g} / \mathrm{mL}$ ) of the differentially DF uploaded nanoparticles, either Tb-doped or undoped, were added in $100 \mu \mathrm{L}$ of fresh medium. Hydrogen peroxide $(1 \mu \mathrm{M})$ was used as control of toxicity. After $72 \mathrm{~h}$ incubation, cell viability was evaluated by the 3-(4,5-Dimethylthiazol-2-yl)-2,5-diphenyltetrazolium bromide) (MTT, Sigma) colorimetric assay, and the optical density was measured in a multiwell reader (2030 Multilabel Reader Victor TM X4, Perkin Elmer, Beaconsfield, UK) at $570 \mathrm{~nm}$, as described [23]. In the case of hOB and differentiated hOB (15,000 cells/wells in 96-well plates) the assay was continued for 7 days, with careful medium changes every 3-4 days. Viability of parallel cultures of untreated cells was used as $100 \%$ viability, and values obtained from cells undergoing the different treatments were referred to this value. Experiments were performed 3 times using 3 replicates for each sample.

\subsection{Inflammatory Cytokine Treatment}

hOS, both induced and not, were seeded at a concentration of 15,000 cells / microwell and when $95 \%$ confluent (after about 3-4 days) recombinant human IL-1 $\beta$, human TNF- $\alpha$ and human IFN- $\gamma$ (ImmunoTools $\mathrm{GmbH}$, Friesoythe, Germany) were added in complete culture medium at final concentrations of 1, 10, $100 \mathrm{ng} / \mathrm{mL}$, respectively (cytokine mix), following a published protocol with some modifications [43]. The following day medium was changed with all cytokine concentrations reduced to 1:4 and after a further day the medium with the same cytokine concentration was changed and $50 \mu \mathrm{g} / \mathrm{mL}$ of UV-sterilized Tb-doped NPs functionalized with DF or not and comparable amounts of soluble DF were 
added. Medium was then changed on day 3, maintaining the same concentrations of cytokines and of the different NPs and controls. Some experiments lasted 1 or 5 days.

\subsection{Quantitative Real-Time PCR ( $q P C R)$}

hOS $(500,000 / 6 \mathrm{~cm}$ diameter plate) were seeded and when confluent they were treated for induction of inflammation by the addition of the cytokines mixture. After $24 \mathrm{~h} \mathrm{cAp-Tb}$ uploaded with DF or not were added at a concentration of $50 \mu \mathrm{g} / \mathrm{mL}$. In this case, $16 \mathrm{~h}$ later, total cell RNAs were extracted with Trizol (Invitrogen Life Technologies, Monza, Italy). After RNA purification and treatment with DNAse I (Fermentas, St. Leon-Rot, Germany), $1 \mu \mathrm{g}$ was retrotranscribed in cDNA with the RevertAid ${ }^{\mathrm{TM}} \mathrm{H}$ Minus First Strand cDNA Synthesis Kit (Fermentas) using oligo(dT) primers. Gene assays were performed in triplicate for each treatment in a $20 \mu \mathrm{L}$ reaction volume containing $1 \mu \mathrm{L}$ of RT products, $10 \mu \mathrm{L}$ Sso-Fast EVA Green SMX (Bio-Rad, Hercules, CA, USA), $500 \mathrm{nM}$ each forward and reverse primers (COX-2, Fw: TATCACAGGCTTCCATTGACC; Rev: TTTCTACCAGAAGGGCAGGAT) [44]. Gene expression was normalized on the housekeeping gene ribosomal 18S rRNA (Fw: 5'-GTGGAGCGATTTGTCTGGTT-3'; Rev: $5^{\prime}$-ACGCTGAGCCAGTCAGTGTA-3'). Automated CFX96 real-time thermocycler (BioRad) was used and the reaction conditions were $95^{\circ} \mathrm{C}$ for $1 \mathrm{~min}$, followed by 45 cycles at $98^{\circ} \mathrm{C}$ for $5 \mathrm{~s}$ and anneal/extend step for $5 \mathrm{~s}$ at $60^{\circ} \mathrm{C}$, with data collection. At the end of these cycles, a melting curve $\left(65{ }^{\circ} \mathrm{C}\right.$ to $95^{\circ} \mathrm{C}$, with plate read every $\left.0.5^{\circ} \mathrm{C}\right)$ was performed to assess the specificity of the amplification product by single peak melting temperature verification. Results were analysed with Bio-Rad CFX Manager. Calculations and statistical analyses were performed using GraphPad Prism version 5.00 for Windows (GraphPad Software, San Diego, CA, USA).

\subsection{2. $P G E_{2}$ Production}

$\mathrm{PGE}_{2}$ produced by cells and released in the culture medium was evaluated in an ELISA Kit (Cayman kit, Vinci-Biochem, Vinci, Italy), according to the manufacturer's protocol. This is a competitive-binding assay, which was performed on $1 / 5$ diluted samples in triplicates and was repeated twice. Optical absorbance was read at $405 \mathrm{~nm}$.

\subsection{Statistical Analysis}

Data were statistically analysed and are expressed as mean \pm standard deviation. Statistical analyses were performed using a one-way ANOVA with Bonferroni's post test for grouped analyses using GraphPad Prism version 5.04 for Windows, GraphPad Software (GraphPad Prism, San Diego, CA, USA). Differences at $p<0.05$ were considered to be statistically significant.

\section{Results}

\subsection{Characterization of the NPs}

Precipitation experiments yielded cAp and $\mathrm{cAp}-\mathrm{Tb} \mathrm{NPs}$ with needle-like morphologies, elongated along the $c$-axis, of $40 \pm 10 \mathrm{~nm}$ and $30 \pm 8 \mathrm{~nm}$, respectively (Figure 1). XRD patterns (see Supplementary Materials, Figure S1) show the diffraction peaks at $2 \theta=25.87^{\circ}$ (002), $31.77^{\circ}, 32.19^{\circ}$ and $32.90^{\circ}$ (planes (211), (112) and (300)), respectively, at $33.9^{\circ}(202)$ and $\left.39.81^{\circ}(310)\right)$ and minor reflections within the range $38^{\circ}-55^{\circ}$, characteristics of the apatite phase (PDF 01-1008) [29].

FTIR spectra (Figure S2a) display the main band at 1000-1100 $\mathrm{cm}^{-1}$ (asymmetric stretching $v_{3} \mathrm{PO}_{4}$ ), the shoulder at $\sim 965 \mathrm{~cm}^{-1}$ (symmetric stretching $v_{1} \mathrm{PO}_{4}$ ), and the less intense bands at $\sim 608$ and $568 \mathrm{~cm}^{-1}$ (bending mode $v_{4} \mathrm{PO}_{4}$ ). The presence of carbonate $\left(\mathrm{CO}_{3}{ }^{2-}\right)$ is attested by the small band at $873 \mathrm{~cm}^{-1}\left(v_{2} \mathrm{CO}_{3}\right)$ and $v_{3} \mathrm{CO}_{3}$ mode, with bands $\sim 1417 \mathrm{~cm}^{-1}$ and $1468 \mathrm{~cm}^{-1}$. The band at $1590 \mathrm{~cm}^{-1}$ observed in both samples, is ascribed to the antisymmetric stretching frequencies of the carboxylate groups of the citrate, indicating the citrate molecules are adsorbed on the apatite surface, as previously reported [27]. On the other hand, the complementary characterization by Raman (Figure S2b) reveals 
the main band at $960 \mathrm{~cm}^{-1}$ which corresponds to the antisymmetric vibration mode of phosphate groups $\left(v_{1} \mathrm{PO}_{4}\right)$ of the apatite phase [45]. The elemental composition of the new cAp-Tb sample revealed by ICP-MS and thermoanalysis yields $30.78 \mathrm{wt} \% \mathrm{Ca}, 14.44 \mathrm{wt} \% \mathrm{P}$, $0.69 \mathrm{wt} \% \mathrm{~Tb}, 2.23 \mathrm{wt} \% \mathrm{C}$, and $0.53 \mathrm{wt} \% \mathrm{H}$.

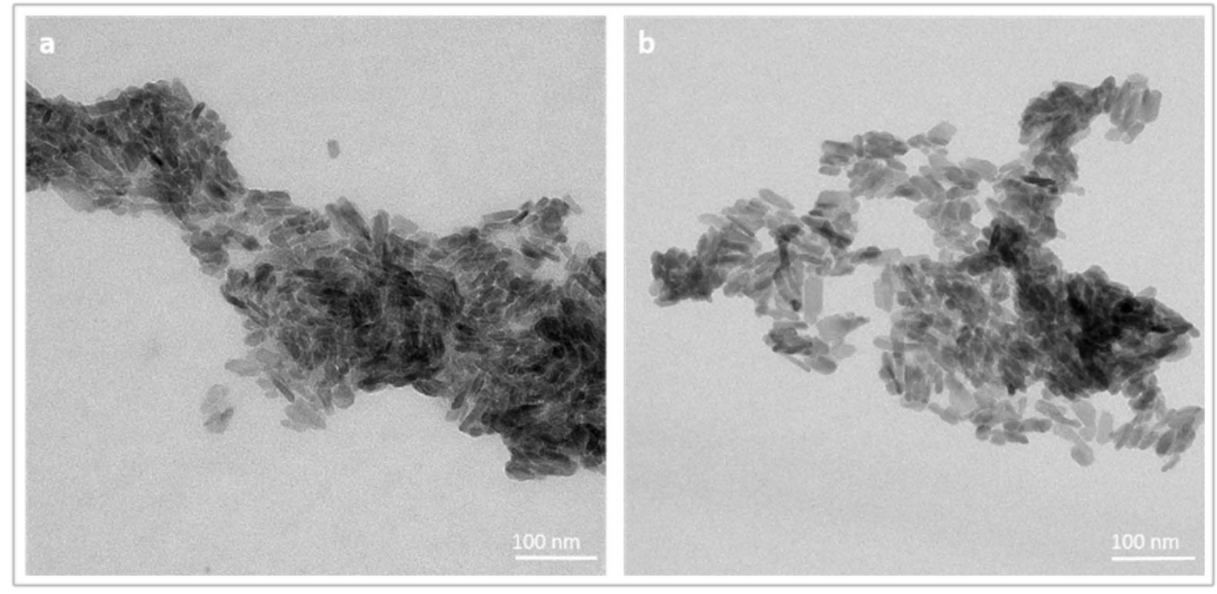

Figure 1. TEM micrographs of cAp (a) and cAp-Tb NPs (b) prepared by thermal decomplexing method $[27,29]$.

The measurements of DLS of the dispersed nanoparticles in aqueous media are shown in Figure S3, which displays the plots as a) PSD in volume and b) cumulative volume oversize distribution. The last one shows $\mathrm{D}_{10}$ percentiles for $\mathrm{cAp}$ and $\mathrm{cAp}-\mathrm{Tb}$ of 55 and $75 \mathrm{~nm}$, respectively, which are close to the individual particle size observed by TEM. The $\mathrm{D}_{50}$ percentiles (75 and $276 \mathrm{~nm}$ ) are affected by aggregation, especially in the cAp- $\mathrm{Tb}$ sample. The $\mathrm{D}_{90}$ are highly affected by aggregation.

\subsection{Adsorption Isotherms}

The evolution of the adsorbed amount of DF per unit mass of adsorbent $\left(Q_{\text {ads }}\right)$ with the time on both substrates (Figure S4) draws different profiles but reveals that adsorption equilibrium is reached after about $15 \mathrm{~h}$. Thus, the adsorption experiments for the elaboration of the isotherms were performed at $24 \mathrm{~h}$, to assure that all points were determined after reaching the equilibrium.

Figure 2 shows the adsorption isotherms ( $Q_{a d s}$ vs. $\left.C_{e q}\right)$ of DF on cAp at $25{ }^{\circ} \mathrm{C}$ (a) and $37^{\circ} \mathrm{C}(\mathrm{c})$, and on $\mathrm{cAp}-\mathrm{Tb}$ at $25^{\circ} \mathrm{C}(\mathrm{e})$ and $37^{\circ} \mathrm{C}(\mathrm{g})$. Adsorption data were fitted to different adsorption models: Langmuir [44-48], Freundlich [49] and Langmuir-Freundlich [30,50,51]. The Langmuir model considers a monolayer of adsorbate and the surface of the adsorbent energetically homogeneous. The linearized equation is described as:

$$
1 / Q_{e q}=1 / Q_{\max }+1 /\left(Q_{\max } K_{L} C_{e q}\right)
$$

being $Q_{\max }$ the maximum adsorbed amount per unit mass of adsorbent $(\mathrm{mg} / \mathrm{mg})$ and $K_{L}$ the Langmuir affinity constant $(\mathrm{L} / \mathrm{mg})$. The Freundlich model considers an energetically heterogeneous surface and multilayer adsorption. The linearized equation is:

$$
\log Q_{e q}=\log K_{F}+1 / n \log C_{e q}
$$

where the Freundlich constant $K_{F}$ and $1 / n$ are related to the adsorption capacity of the substrate and the intensity of the adsorption, respectively. The third model, LangmuirFreundlich, is more versatile, and simulate both behaviours. The linearized equation is the following:

$$
\ln \left(Q /\left(Q_{\max }-Q\right)\right)=r \ln K_{L F}+r \ln C_{e q}
$$



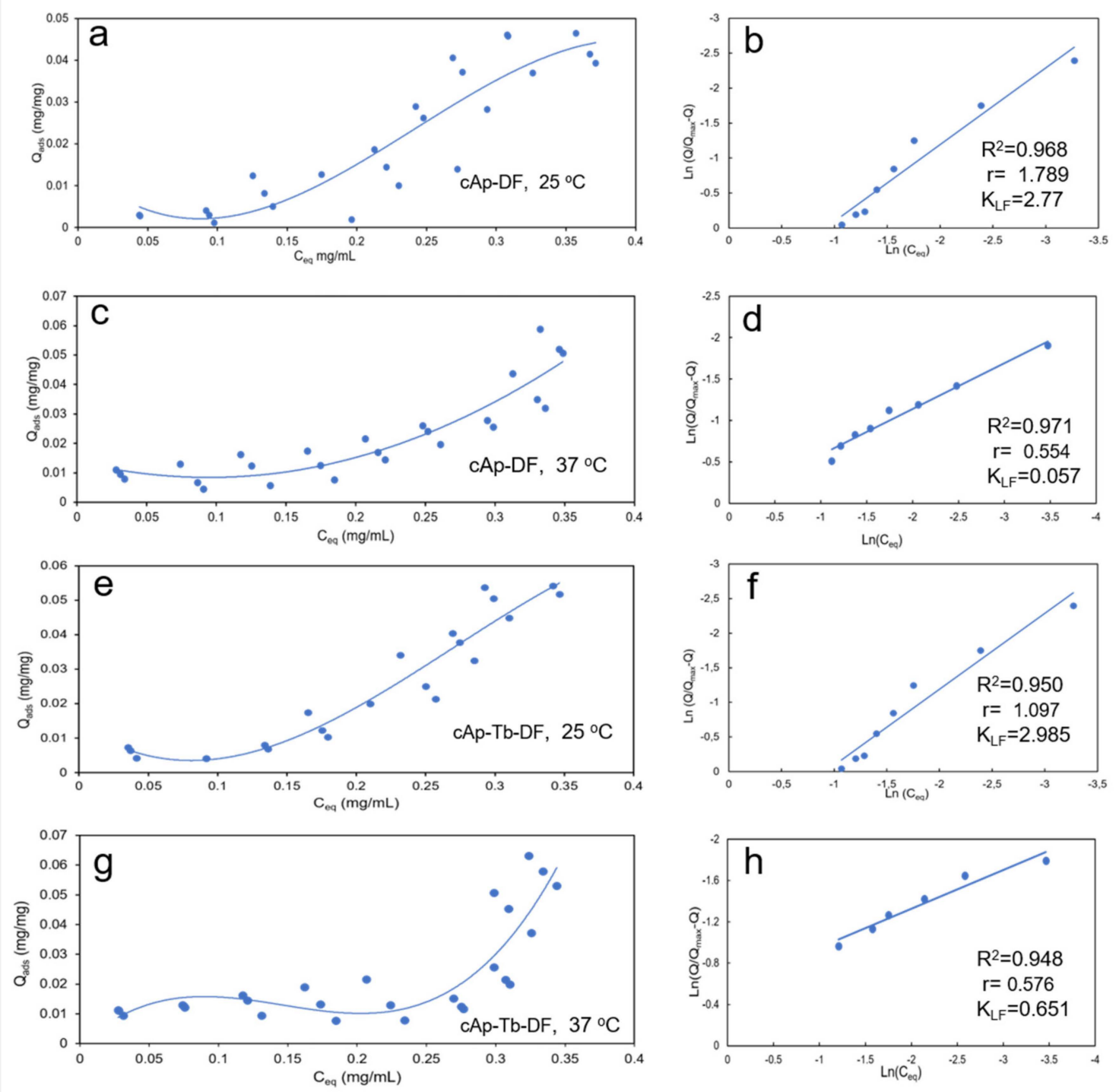

Figure 2. Adsorption isotherms of DF in (a) cAp at $25^{\circ} \mathrm{C}$, (c) cAp at $37^{\circ} \mathrm{C},(\mathbf{e}) \mathrm{cAp}-\mathrm{Tb}$ at $25^{\circ} \mathrm{C}$, and (g) cAp- $\mathrm{Tb}$ at $37^{\circ} \mathrm{C}$. Fitting of adsorption data to the Langmuir-Freundlich model (b) cAp at $25^{\circ} \mathrm{C}$, (d) cAp at $37^{\circ} \mathrm{C}$, (f) cAp-Tb at $25^{\circ} \mathrm{C}$, and (h) cAp- $\mathrm{Tb}$ at $37^{\circ} \mathrm{C}$.

In equation $4 K_{L F}$ is the Langmuir-Freundlich constant and $r$ the cooperativity coeficient, with $r>1$ indicating a positive cooperativity or $r<1$ negative cooperativity [50].

Only the Langmuir-Freundlich model fitted reasonably the adsorption data (Figure $2 \mathrm{~b}, \mathrm{~d}, \mathrm{f}, \mathrm{h}$ ), with regression coefficients $\left(\mathrm{R}^{2}\right)$ higher than 0.97 and 0.95 for cAp and cAp- $\mathrm{Tb}$ experiments, respectively, whereas the other two models yielded $\mathrm{R}^{2}<0.7$. This indicates that DF adsorbs in multilayers with a limited number of layers. The $K_{L F}, r$ and $Q_{\max }$ values obtained by this model are shown in Table 1.

We can appreciate that at $25^{\circ} \mathrm{C}$ the $K_{L F}$ values for cAp and cAp- $\mathrm{Tb}$ are higher than at $37^{\circ} \mathrm{C}$, revealing the higher affinity of DF molecules for the adsorbent at this temperature. In addition, the $r$ values at $25^{\circ} \mathrm{C}$ are higher than 1 , while at $37^{\circ} \mathrm{C}$ are lower, indicating the process is cooperative at $25^{\circ} \mathrm{C}$ and non-cooperative at $37^{\circ} \mathrm{C}$. However, $Q_{\max }$ is always higher in the $\mathrm{cAp}-\mathrm{Tb}$ substrate irrespective of the temperature. 
Table 1. Regression coefficients and parameters $K_{L F}, r$ and $Q_{\max }$ determined from LangmuirFreundlich model.

\begin{tabular}{cccccc}
\hline Substrate, $T\left({ }^{\circ} \mathrm{C}\right)$ & $\mathbf{R}^{2}$ & $K_{L F}$ & $r$ & $Q_{\max }(\mathbf{m g} / \mathbf{m g})$ & Adsorption Type \\
\hline $\mathrm{cAp}, 25{ }^{\circ} \mathrm{C}$ & 0.9679 & 2.77 & 1.794 & 0.04648 & $\begin{array}{c}\text { Cooperative, high } \\
\text { affinity }\end{array}$ \\
\hline $\mathrm{CAp}, 37^{\circ} \mathrm{C}$ & 0.9709 & 0.05 & 0.5536 & 0.05067 & $\begin{array}{c}\text { Non-cooperative, } \\
\text { low affinity }\end{array}$ \\
\hline $\mathrm{cAp}-\mathrm{Tb}, 25^{\circ} \mathrm{C}$ & 0.9503 & 2.98 & 1.0973 & 0.05411 & $\begin{array}{c}\text { Cooperative, high } \\
\text { affinity }\end{array}$ \\
\hline $\mathrm{CAp}-\mathrm{Tb}, 37^{\circ} \mathrm{C}$ & 0.9482 & 0.65 & 0.3751 & 0.06306 & $\begin{array}{c}\text { Non-cooperative, } \\
\text { low affinity }\end{array}$ \\
\hline
\end{tabular}

\section{3. $\zeta$-Potential versus $p H$ of Unloaded and DF-Loaded cAp and cAp-Tb NPs Suspensions}

The measurements of $\zeta$-potential of both type of unloaded NPs (blue lines in Figure 3 ) reveal a decrease to more negative values with increasing the $\mathrm{pH}$, especially for the sample cAp- $\mathrm{Tb}$, with values of $-19 \mathrm{mV}(\mathrm{pH} 7)$ and of $-16 \mathrm{mV}(\mathrm{pH}$ 5). This indicates that NPs tend to be dispersed in aqueous media at physiological and acidic pHs, which is a desirable feature in view of their applications in nanomedicine.
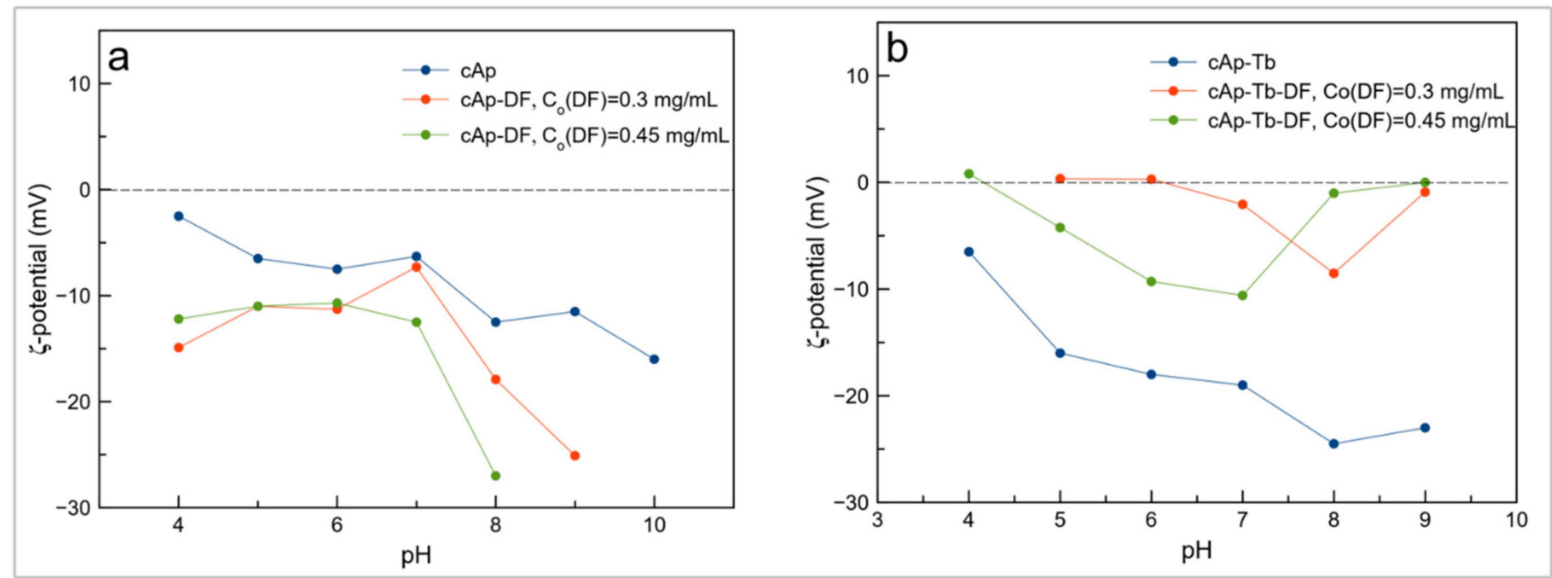

Figure 3. Plots $\zeta$-potential versus pH: (a) cAp (blue), cAp-DF loaded in solutions of DF $0.3 \mathrm{mg} / \mathrm{mL}$ (red) $\left(Q_{a d s}=0.02304 \mathrm{mg} / \mathrm{mg}\right)$ and cAp-DF loaded in solutions of $\mathrm{DF} 0.45 \mathrm{mg} / \mathrm{mL}$ (green) $\left(Q_{a d s}=0.04246 \mathrm{mg} / \mathrm{mg}\right.$ ). (b) cAp-Tb (blue), cAp-Tb-DF loaded in solutions of DF $0.3 \mathrm{mg} / \mathrm{mL}$ (red) $\left(Q_{a d s}=0.02680 \mathrm{mg} / \mathrm{mg}\right)$ and cAp-Tb-DF loaded in solutions of $\mathrm{DF} 0.45 \mathrm{mg} / \mathrm{mL}$ (green) $\left(Q_{a d s}=0.04435 \mathrm{mg} / \mathrm{mg}\right)$.

However, when loading the nanoparticles with DF in solutions of concentrations 0.3 and $0.45 \mathrm{mg} / \mathrm{mL}$, we found a different behaviour depending on the type of adsorbent. Thus, when loading cAp, the $\zeta$-potential of cAp-DF nanoassemblies decreases (more negative), especially when their payload is higher. The behaviour is the opposite when loading $\mathrm{cAp}$ - $\mathrm{Tb}$ nanoparticles, being the $\zeta$-potential of the cAp-Tb-DF nanoassemblies higher (less negative), especially when they were loaded in the solution with the lower $\mathrm{DF}$ concentration at $\mathrm{pH} \leq 7$. This finding reveals a higher tendency of the $\mathrm{cAp}-\mathrm{Tb}-\mathrm{DF}$ nanoassemblies to aggregate. Nevertheless, for the cAp-Tb-DF sample $\left(C_{0}=0.45 \mathrm{mg} / \mathrm{mL}\right.$ $\mathrm{DF}, Q_{a d s}=0.04435 \mathrm{mg} / \mathrm{mg}$ ), the $\zeta$-potentials are still negative being $-4.2 \mathrm{mV}$ at $\mathrm{pHs} 5$ and $-10.6 \mathrm{mV}$ at $\mathrm{pH} 7$.

\subsection{Release Profiles and Release Efficiency}

Figure 4 shows the DF release profiles ( $C_{\text {des }}$ vs. time) at $\mathrm{pH} 7.4(\mathrm{a}, \mathrm{b})$ and $5.2(\mathrm{c}, \mathrm{d})$ by comparing the effect of the temperature $\left(25\right.$ and $\left.37^{\circ} \mathrm{C}\right)$ for both types of nanoparticles. It is 
observed that at $\mathrm{pH} 7.4$ the released DF mass per $\mathrm{mL}$ of buffer solution at $37^{\circ} \mathrm{C}$ is slightly higher than at $25^{\circ} \mathrm{C}$, and always higher for cAp than from cAp-Tb. At pH 5.2 the released amount from cAp-DF at $37^{\circ} \mathrm{C}$ even increases within the time interval of the experiment (Figure 4c). It is worth mentioning the peculiar release profile of the $\mathrm{cAp}-\mathrm{Tb}$ substrate at $37^{\circ} \mathrm{C}$, which shows a burst during the first $10 \mathrm{~h}$, and then stabilizing with time.
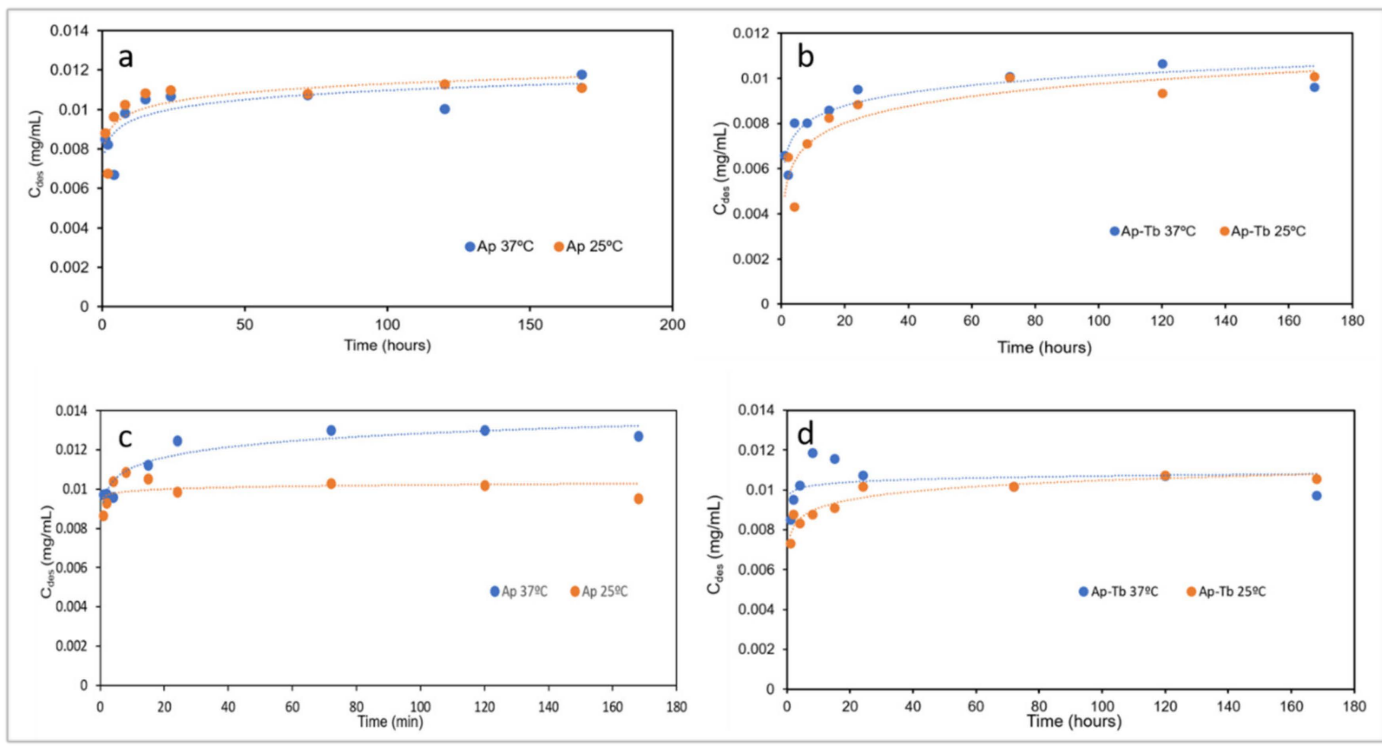

Figure 4. Release profiles of DF from (a) cAp-DF at 25 and $37^{\circ} \mathrm{C}, \mathrm{pH} 7.4 ;(\mathbf{b}) \mathrm{cAp}-\mathrm{Tb}-\mathrm{DF}$ at 25 and $37^{\circ} \mathrm{C}$, pH 7.4; (c) cAp-DF at 25 and $37^{\circ} \mathrm{C}, \mathrm{pH} 5.2$, and (d) cAp-Tb-DF at 25 and $37^{\circ} \mathrm{C}, \mathrm{pH} 5.2$.

When comparing the effect of $\mathrm{pH}$ (7.4 and 5.2) on the release of DF a higher release was observed at $\mathrm{pH} 5.2$ (citrate buffer) than at $\mathrm{pH} 7.4$ (PBS buffer), at both temperatures, with the only exception for $\mathrm{cAp}$ at $25{ }^{\circ} \mathrm{C}$ after the first $10 \mathrm{~h}$ of the experiment, when the delivery trend versus $\mathrm{pH}$ is the opposite (Figure $5 \mathrm{a}-\mathrm{d}$ ). This $\mathrm{pH}$-responsive drug release behaviour is very useful concerning DF delivery in pathological environments.
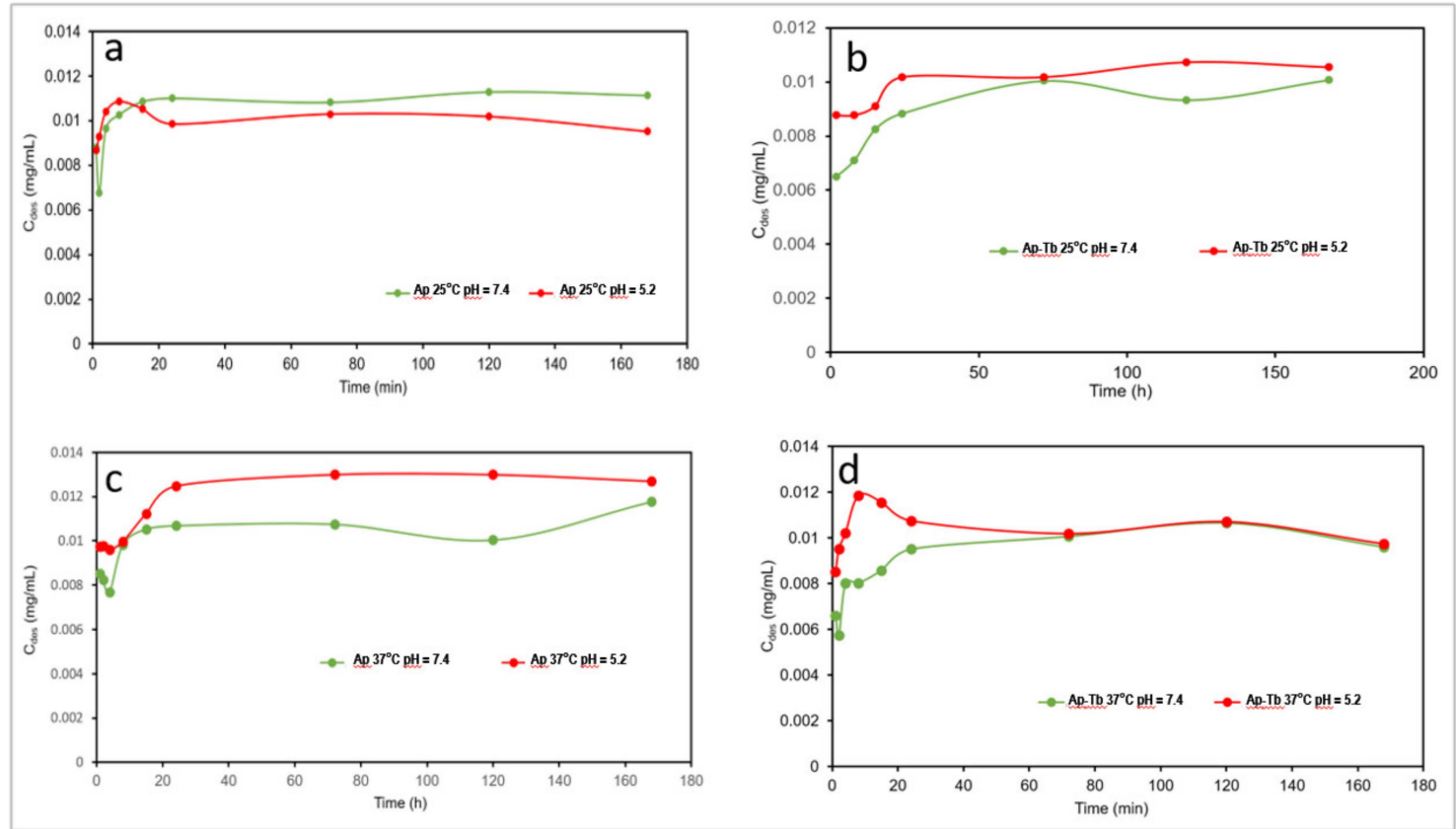

Figure 5. Release kinetics of DF from cAp-DF at $25^{\circ} \mathrm{C}$ (a) and $37^{\circ} \mathrm{C}$ (c) and from cAp-Tb-DF at $25^{\circ} \mathrm{C}$ (b) and at $37^{\circ} \mathrm{C}$ (d) at $\mathrm{pH} 7.4$ (green line) and 5.2 (red line). 
The release efficiency $\operatorname{Dr}[30,50]$ defined as the percentage of drug released at a given time $(t)$ respect to maximum amount of drug adsorbed (Equation (5)),

$$
\operatorname{Dr}(\% w t)=Q_{t} / Q_{\max } \times 100
$$

revealed that considering the larger times of the experiment, $D r$ and $Q_{D, \max }$ for cAp-DF are in general larger than for cAp-Tb-DF at both $\mathrm{pHs}$ (see Table 2). This trend is just the opposite to that found in the adsorption experiments, in which the maximum adsorption corresponded to $\mathrm{cAp}-\mathrm{Tb}$.

Table 2. Maximum released amount of DF per unit mass of adsorbent $\left(Q_{D, m a x}, \mathrm{mg} / \mathrm{mg}\right)$ and $D r$ at pHs 7.4 and 5.2 for cAp-DF and cAp-Tb-DF nanoassemblies.

\begin{tabular}{|c|c|c|c|c|c|c|c|c|}
\hline Parameter & $\begin{array}{c}\text { cAp-DF, } \\
25^{\circ} \mathrm{C} \\
\mathrm{pH}=7.4\end{array}$ & $\begin{array}{c}\text { cAp-DF, } \\
37^{\circ} \mathrm{C} \\
\mathrm{pH}=7.4\end{array}$ & $\begin{array}{c}\text { cAp-Tb- } \\
\text { DF, } 25^{\circ} \mathrm{C} \\
\text { pH }=7.4\end{array}$ & $\begin{array}{c}\text { cAp-Tb- } \\
\text { DF, } 37^{\circ} \mathrm{C} \\
\text { pH }=7.4\end{array}$ & $\begin{array}{c}\text { cAp-DF, } \\
25^{\circ} \mathrm{C} \\
\mathrm{pH}=5.2\end{array}$ & $\begin{array}{c}\text { cAp-DF, } \\
37^{\circ} \mathrm{C} \\
\mathrm{pH}=5.2\end{array}$ & $\begin{array}{c}\text { cAp-Tb- } \\
\text { DF, } 25^{\circ} \mathrm{C} \\
\text { pH }=5.2\end{array}$ & $\begin{array}{c}\text { cAp-Tb DF, } \\
37^{\circ} \mathrm{C} \\
\mathrm{pH}=5.2\end{array}$ \\
\hline $\begin{array}{c}Q_{D \max } \\
(\mathrm{mg} / \mathrm{mg})\end{array}$ & 0.01128 & 0.01177 & 0.01007 & 0.01066 & 0.01048 & 0.01300 & 0.01073 & 0.01185 \\
\hline $\operatorname{Dr}(\% \mathrm{wt})$ & 24.26 & 23.24 & 18.55 & 16.90 & 23.33 & 25.66 & 19.84 & 18.79 \\
\hline
\end{tabular}

\subsection{Luminescence Properties of Unloaded and DF-Loaded cAp and cAp-Tb NPS Suspensions}

It is well-known that $\mathrm{Tb}^{3+}$ - luminescent chelates shows narrow-banded, line-type fluorescence with long Stokes shifts and high luminescence decay times [52]. This luminescent emission can be used for sensitized fluorescence detection of chelates [53], the development of FRET analytical methods [54], as well as for the incorporation of luminescent properties to materials in order to develop new imaging applications $[29,34]$. In this work, $\mathrm{Tb}^{3+}$ was incorporated to provide the nanocarrier with a luminescence signal which can be measured to determine where the particles are located.

Figure 6 shows the excitation and emission spectra of NPs dispersed in aqueous media at $\mathrm{pH} 5.2$ at $37^{\circ} \mathrm{C}$ which are similar to those obtained for 25 and $40{ }^{\circ} \mathrm{C}$ as well as for $\mathrm{pH} 7.4$ at these three temperatures (see Supplementary Materials Figures S5-S9).

Concerning the excitation wavelength $\left(\lambda_{\text {exc }}\right)$, these particles can be excited at the Charge Tranfer Band, CTB [55], (centred at $230 \mathrm{~nm}$ approximately) obtaining the same emission spectra as that obtained by exciting at $350 \mathrm{~nm}$ [34]. In order to increase the biological applicability of the system, $350 \mathrm{~nm}$ (corresponding to the $\mathrm{Tb}^{3+}{ }^{7} \mathrm{~F}_{6} \rightarrow{ }^{5} \mathrm{~L}_{9},{ }^{5} \mathrm{D}_{2},{ }^{5} \mathrm{G}_{5}$ transition [56] was selected as excitation wavelength.

Concerning the emission wavelengths $\left(\lambda_{\mathrm{em}}\right)$, they are centred at 491, 545, 586 and $623 \mathrm{~nm}$, corresponding to the $\mathrm{Tb}^{3+}{ }^{5} \mathrm{D}_{4} \rightarrow{ }^{7} \mathrm{~F}_{6},{ }^{5} \mathrm{D}_{4} \rightarrow{ }^{7} \mathrm{~F}_{5},{ }^{5} \mathrm{D}_{4} \rightarrow{ }^{7} \mathrm{~F}_{4}$ and ${ }^{5} \mathrm{D}_{4} \rightarrow{ }^{7} \mathrm{~F}_{3}$ transitions, respectively [57]. The emission wavelength which produces the highest relative luminescence intensity (R.L.I.) corresponds to the hypersensitive transition without inversion centre $\left({ }^{5} \mathrm{D}_{4} \rightarrow{ }^{7} \mathrm{~F}_{5}, 545 \mathrm{~nm}\right.$ for $\left.\mathrm{Tb}^{3+}\right)$ Therefore, the optimum $\lambda_{\text {exc }}$ and $\lambda_{\mathrm{em}}$ of solid particles were 350 and $545 \mathrm{~nm}$, respectively.

Figure 7 shows the effect of DF concentration. It is possible to conclude that the adsorption of DF on the particles does not affect significantly the $\mathrm{Tb}^{3+}$ luminescence emission. Therefore, this signal cannot be used to determine if DF is released or not. 


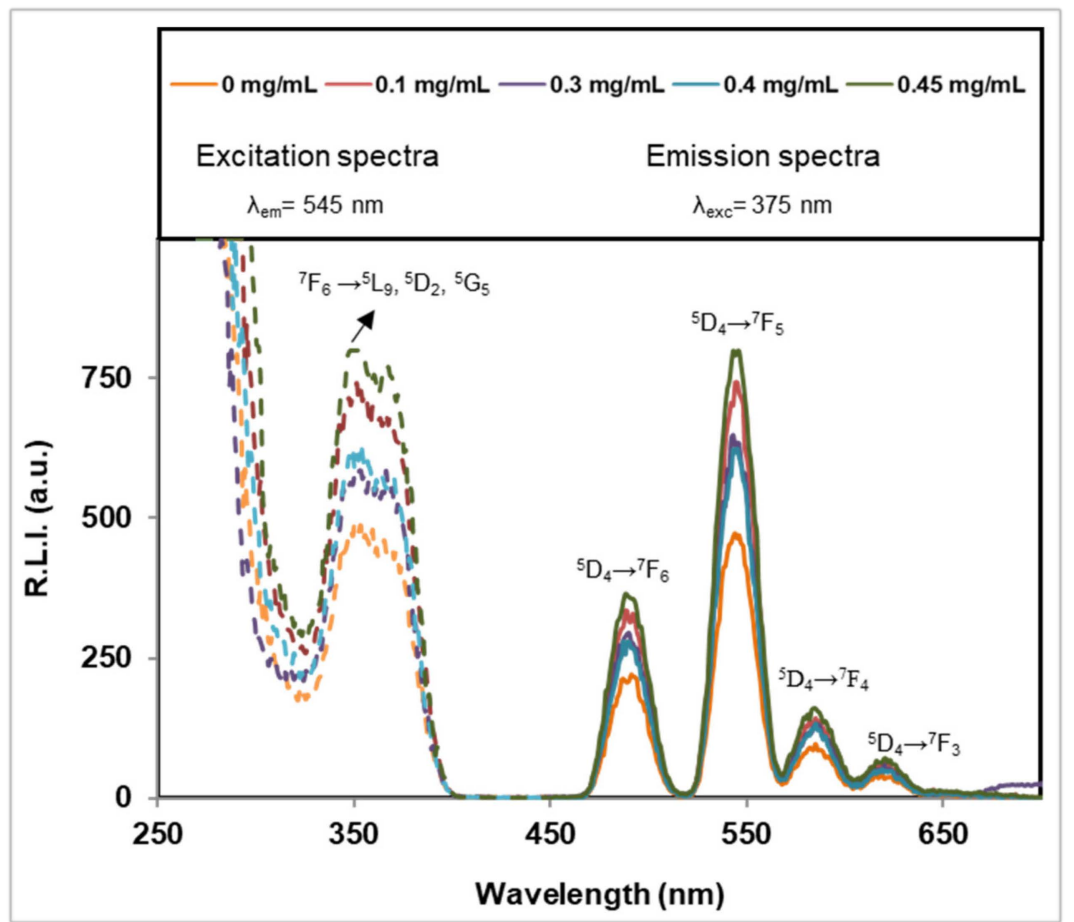

Figure 6. Excitation (dashed lines) and emission (solid lines) uncorrected spectra of cAp-TbDF samples containing different DF adsorbed amounts, dispersed in a pH 5.2 aqueous suspension at $0.5 \mathrm{mg} / \mathrm{mL}$ and $37{ }^{\circ} \mathrm{C}$. The instrumental conditions were $t_{d}=120 \mu \mathrm{s}, \mathrm{t}_{\mathrm{g}}=5 \mathrm{~ms}$, slitwidth $_{\text {exc } / \mathrm{em}}=20 \mathrm{~nm} / 20 \mathrm{~nm}$ and detector voltage $750 \mathrm{~V}$.
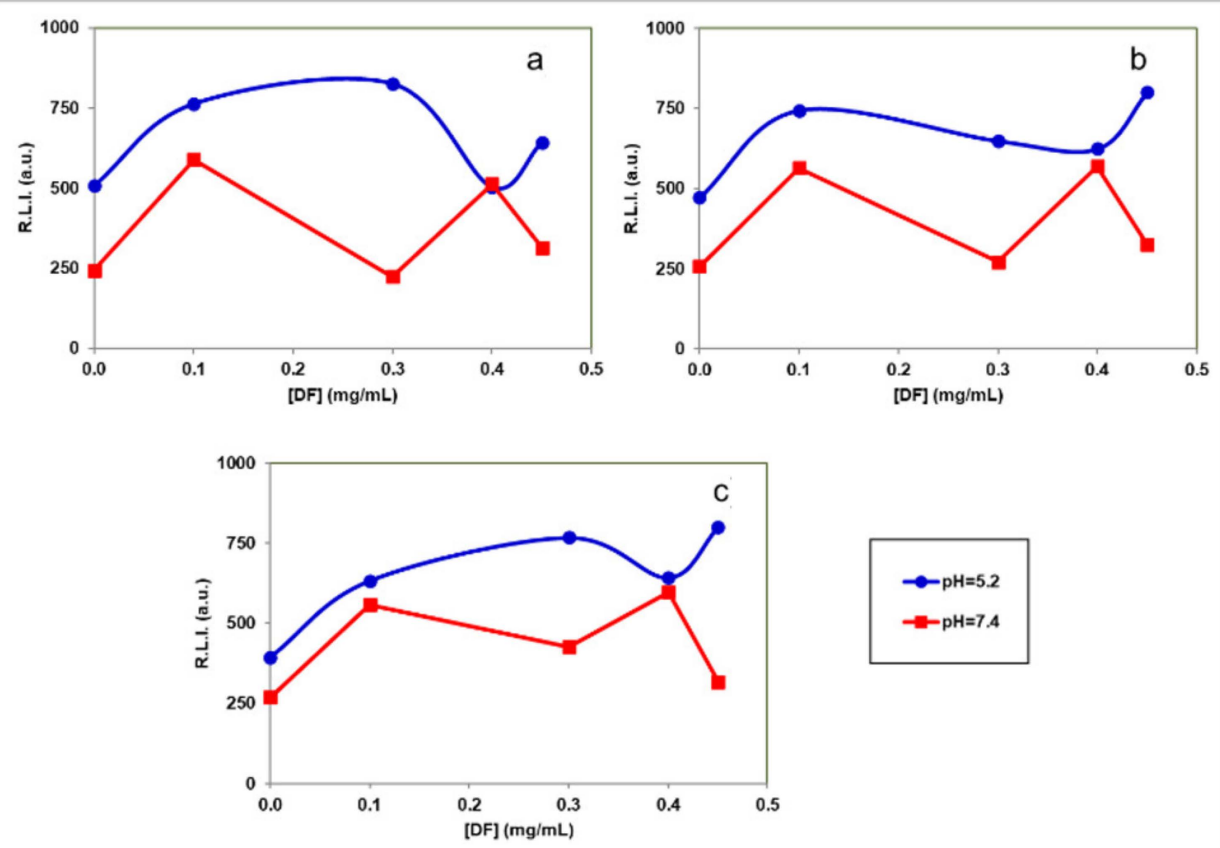

Figure 7. Effect of the DF concentration on the R.L.I. of the particles suspended in aqueous suspension at different $\mathrm{pHs}$ and temperatures: $(\mathbf{a}) \mathrm{T}=25^{\circ} \mathrm{C},(\mathbf{b}) \mathrm{T}=37^{\circ} \mathrm{C}$ and $(\mathbf{c}) \mathrm{T}=40^{\circ} \mathrm{C}$. Excitation (dashed lines) and emission (solid lines) uncorrected spectra of samples containing different DF concentrations dispersed in a pH 5.2 aqueous suspension at $0.5 \mathrm{mg} / \mathrm{mL}$ and $37^{\circ} \mathrm{C}$. The instrumental conditions were $\lambda_{\text {exc } / \mathrm{em}}=350 / 545 \mathrm{~nm}, \mathrm{t}_{\mathrm{d}}=120 \mu \mathrm{s}, \mathrm{t}_{\mathrm{g}}=5 \mathrm{~ms}$, slitwidth exc $/ \mathrm{em}=20 / 20 \mathrm{~nm}$ and detector voltage $750 \mathrm{~V}$.

Figure 8 shows the effect of $\mathrm{pH}$ and temperature. We can observe that, at all tested DF concentrations, the signals at pH 5.2 are higher than those obtained at pH 7.4. Thus, 
the luminescence emission of these particles could be used to determine $\mathrm{pH}$ changes, which are related to inflammatory processes. In addition, it is possible to conclude that the luminescence signal is not affected between 25 and $40{ }^{\circ} \mathrm{C}$ demonstrating that it can be used for biological applications, since the luminescence is not affected by local increases of temperature due to inflammatory processes.
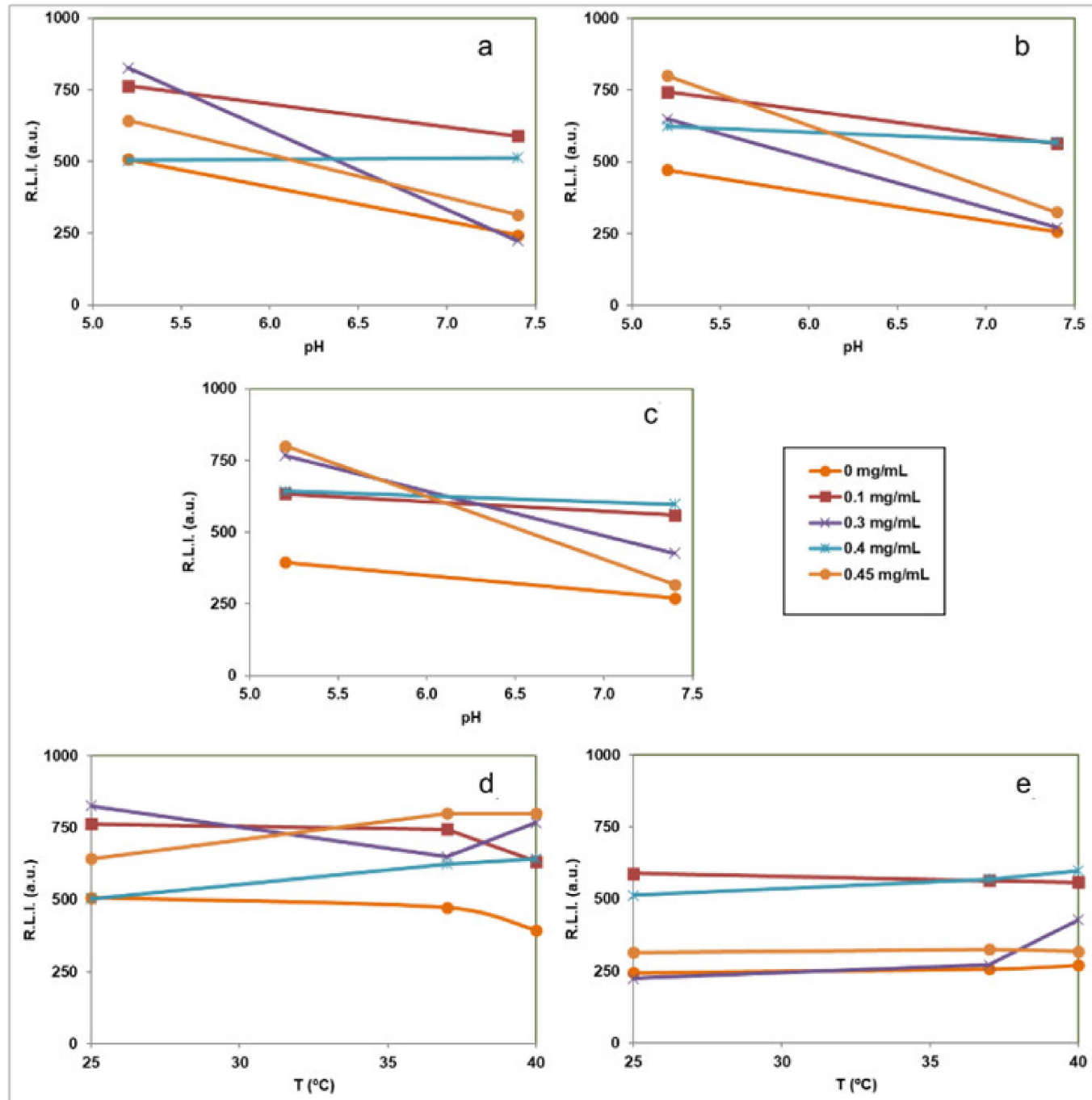

Figure 8. Effect of the $\mathrm{pH}$ and the temperature on the R.L.I. of the cAp-Tb-DF with different amounts of DF adsorbed suspended in aqueous media at different $\mathrm{pHs}$ and temperatures $\left[(\mathbf{a}) 25^{\circ} \mathrm{C},(\mathbf{b}) 37^{\circ} \mathrm{C}\right.$ and (c) $40^{\circ} \mathrm{C}$, (d) $\mathrm{pH} 5.2$ and (e) $\mathrm{pH} 7.4$ ]. In all measurements the concentration of the suspended particles was $0.5 \mathrm{mg} / \mathrm{mL}$ and the instrumental conditions were $\lambda_{\text {exc } / \mathrm{em}}=350 / 545 \mathrm{~nm}, \mathrm{t}_{\mathrm{d}}=120 \mu \mathrm{s}$, $\mathrm{t}_{\mathrm{g}}=5 \mathrm{~ms}$, slitwidth $\mathrm{exc}_{\mathrm{em}}=20 / 20 \mathrm{~nm}$ and detector voltage $750 \mathrm{~V}$.

Figures S10-S15 in Supplementary Materials show the luminescence decay curves. For each case, the decay profile was analysed as a single exponential component (Equation 6)

$$
\text { R.L.I. }=e^{\left(-\frac{t}{\tau}\right)}+C
$$

Figure 9 shows the variation of the luminescence lifetime $(\tau)$ versus DF concentration, $\mathrm{pH}$ and temperature. It is shown that only $\mathrm{pH}$ is affecting the lifetime; larger lifetimes are obtained at $\mathrm{pH} 7.4$ than at $\mathrm{pH} 5.2$ while different DF concentrations and temperatures do not affect the luminescence lifetimes. 


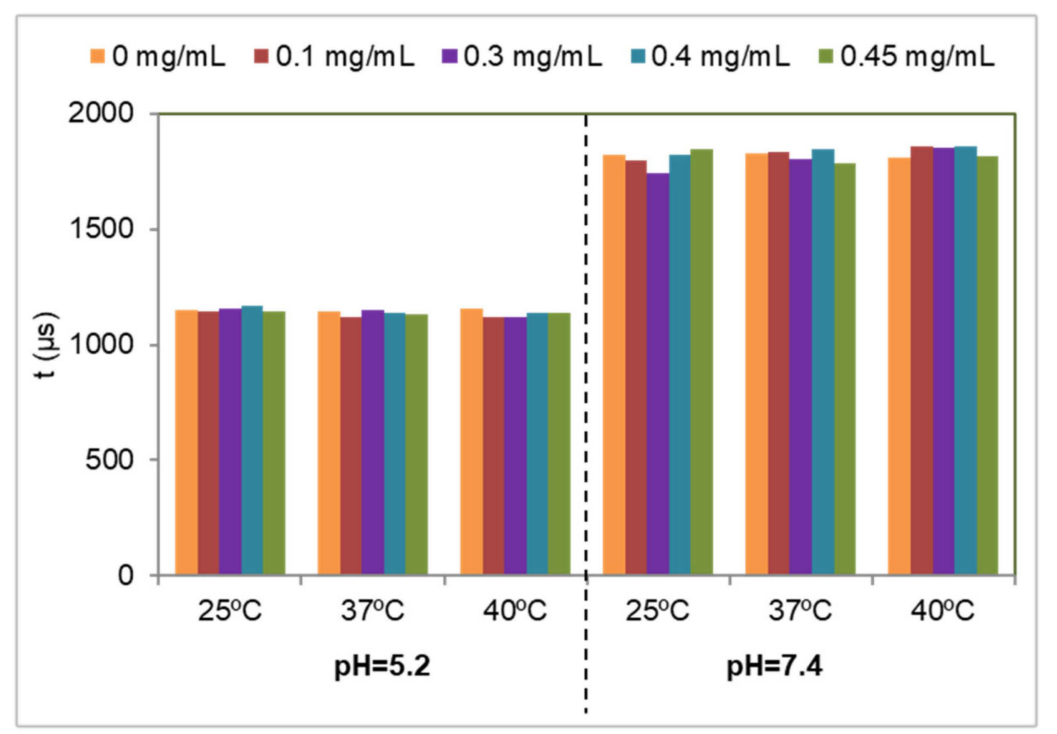

Figure 9. Effect of DF concentration, $\mathrm{pH}$ and temperature on the luminescence lifetime of the particles suspended in aqueous suspension. In all the cases the concentration of the suspended particles was $0.5 \mathrm{mg} / \mathrm{mL}$ and the instrumental conditions were $\lambda_{\text {exc } / \mathrm{em}}=350 / 545 \mathrm{~nm}, \mathrm{t}_{\mathrm{d}}=120 \mu \mathrm{s}, \mathrm{t}_{\mathrm{g}}=0.01 \mathrm{~ms}$, slitwidth $_{\text {exc } / \mathrm{em}}=20 / 20 \mathrm{~nm}$ and detector voltage $900 \mathrm{~V}$.

\subsection{Cytocompatibility of the Different Nanoparticles}

The cytocompatibility of cAp NPs, doped with Tb or not, and uploaded with different concentrations of DF was first assessed on two human osteosarcoma cell lines (MG-63 and U2OS) in MTT assays performed after 3 days of incubation with NPs (Figure 10 and Figure S16). No significant toxicity was observed in any condition; only when cells were incubated with the highest NPs concentration of $100 \mu \mathrm{g} / \mathrm{mL}$ cell viability was decreased, but it was always higher than $80 \%$, which are values above the cut off of $70 \%$ indicated by ISO 10993-5:2009 [58]. cAp NPs cytocompatibility was tested also on primary human osteoblasts (hOB) and on differentiated hOBs, which stained positive for alkaline phosphatase (Figure S17), a typical marker of bone differentiation. In view of the fact that experiments of inflammation would last longer than 3 days, and that $100 \mu \mathrm{g} / \mathrm{mL}$ reduced somehow the viability of the osteosarcoma cell lines, MTT assays were carried out also after 1 week of incubation with NPs and lower doses of NPs, ranging from 50 to $0.5 \mu \mathrm{g} / \mathrm{mL}$ were assessed. Similar data were obtained at the two end-points evidencing no significant reduction in cell viability and results were in line with those obtained with the two osteosarcoma cell lines. In particular Figure 11 shows the results obtained with Tb-doped NPs. All the cells were sensitive to the addition of $1 \mu \mathrm{M}$ hydrogen peroxide, since their viability was reduced to about $30-50 \%$. Thus, these data show the good cytocompatibility of the different nanoparticles that will be used in this study. 


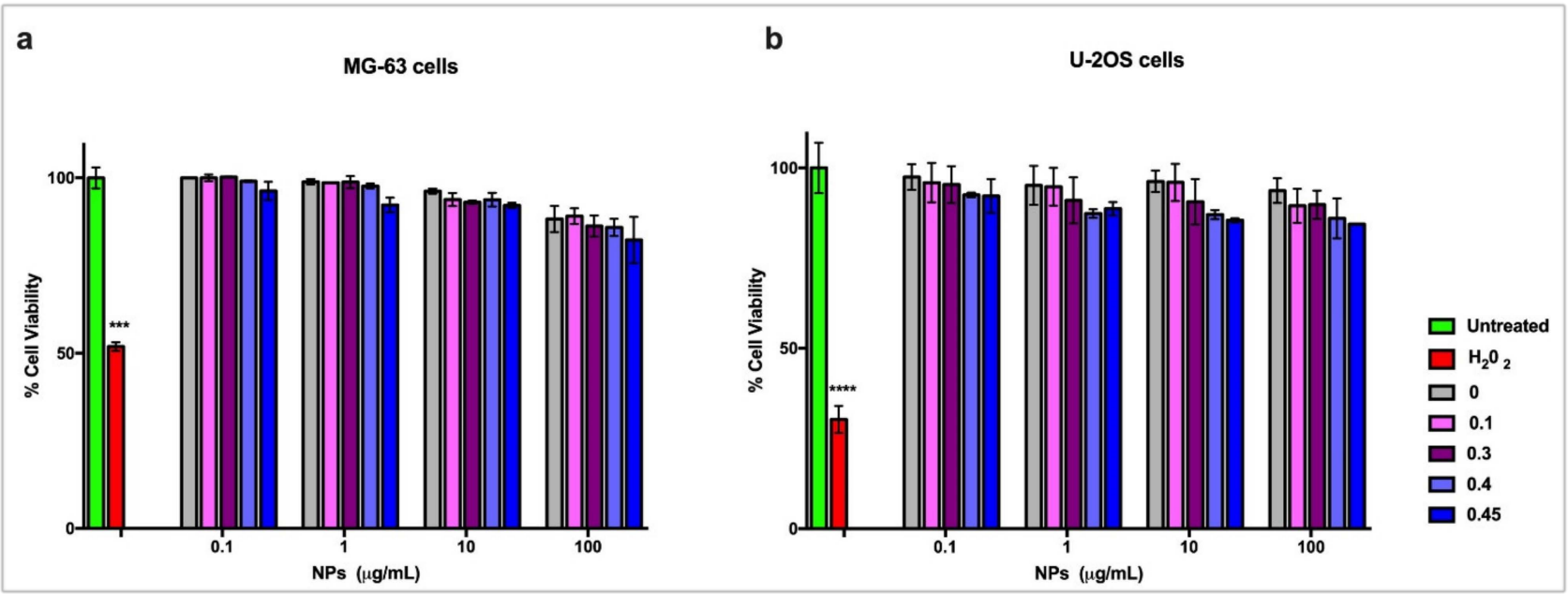

Figure 10. Viability of MG-63 cells (a) and of U-2OS cells (b) incubated with cAp-DF particles loaded with different DF concentration, ranging from 0.1 to $0.45 \mathrm{mg} / \mathrm{mg} \mathrm{NP}$, for three days. Viability was assessed in MTT assays. Data represent means $\pm \mathrm{sd}$ of three independent experiments performed in triplicate and statistical analyses were carried on using One-way ANOVA, with Bonferroni comparison test. For statistical analysis all data were compared to untreated samples and only samples treated with $1 \mu \mathrm{M} \mathrm{H}_{2} \mathrm{O}_{2}$ displayed statistically significant difference $\left.{ }^{* * *} p<0.001,{ }^{* * * *} p<0.0005\right)$.

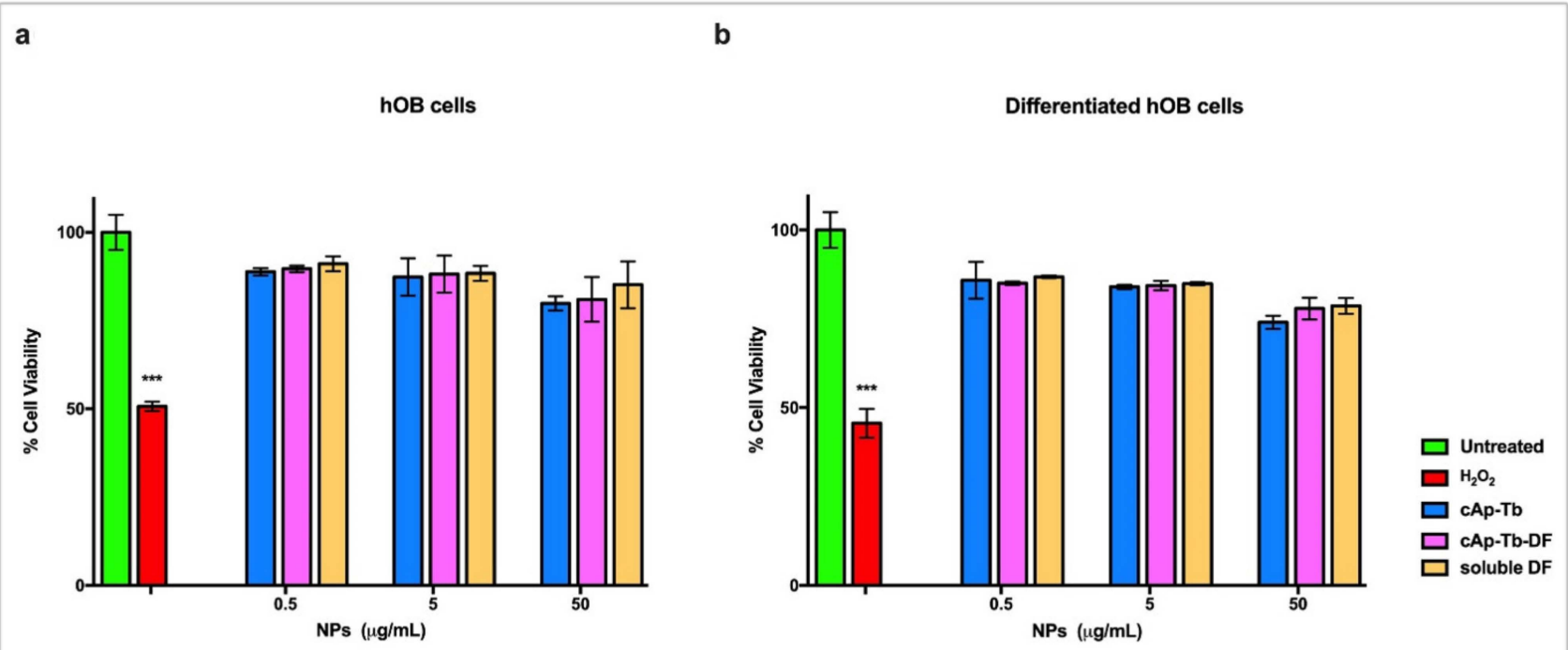

Figure 11. Viability of human primary osteoblasts hOB (a) and of hOB differentiated from mesenchymal stem cells (b) incubated with different concentrations of cAp-Tb particles loaded with DF $(50 \mu \mathrm{g} / \mathrm{mL})$ and unloaded, and comparable soluble DF amounts for seven days. Viability was assessed in MTT assays. Data represent means \pm sd of three independent experiments performed in triplicate and statistical analyses were carried on using One-way ANOVA, with Bonferroni comparison test. For statistical analysis all data were compared to untreated samples and only samples treated with $1 \mu \mathrm{M} \mathrm{H}_{2} \mathrm{O}_{2}$ displayed statistically significant difference (*** $p<0.001$ ).

\subsection{Effect of DF-Loaded Nanoparticles on the Osteoblasts Treated for Inflammation:} COX-2 Expression

To assess the expression of COX-2 mRNA we performed semiquantitative RT-PCR. Differentiated hOB cells showed a low basal expression of the enzyme that was significantly increased after the stimulation with inflammation cytokines for $16 \mathrm{~h}$, as determined by the calculation of relative expression ( $2^{\wedge}-\Delta \Delta \mathrm{Ct}$; Figure 12). The exposure to $\mathrm{cAp}-\mathrm{Tb}$ induced a slightly significant increase of COX-2 expression, indicating a minimal interference of these $\mathrm{NP}$ on cell metabolism. On the other hand, the challenge of hOB cells with soluble DF, a 
potent competitive antagonist of COX-2, did not alter the induction of COX-2 expression evoked by inflammatory stimuli. This observation was also confirmed in the cells treated with cAp-Tb-DF $50 \mu \mathrm{g} / \mathrm{mL}$. Soluble DF $2.5 \mu \mathrm{g} / \mathrm{mL}$ concentration was chosen to pair the amount released from cAp-Tb-DF at $50 \mu \mathrm{g} / \mathrm{mL}$, as described above. These data were related to prostaglandin- $\mathrm{E}_{2}$ release in order to show any possible interaction on COX-2 mRNA expression levels.

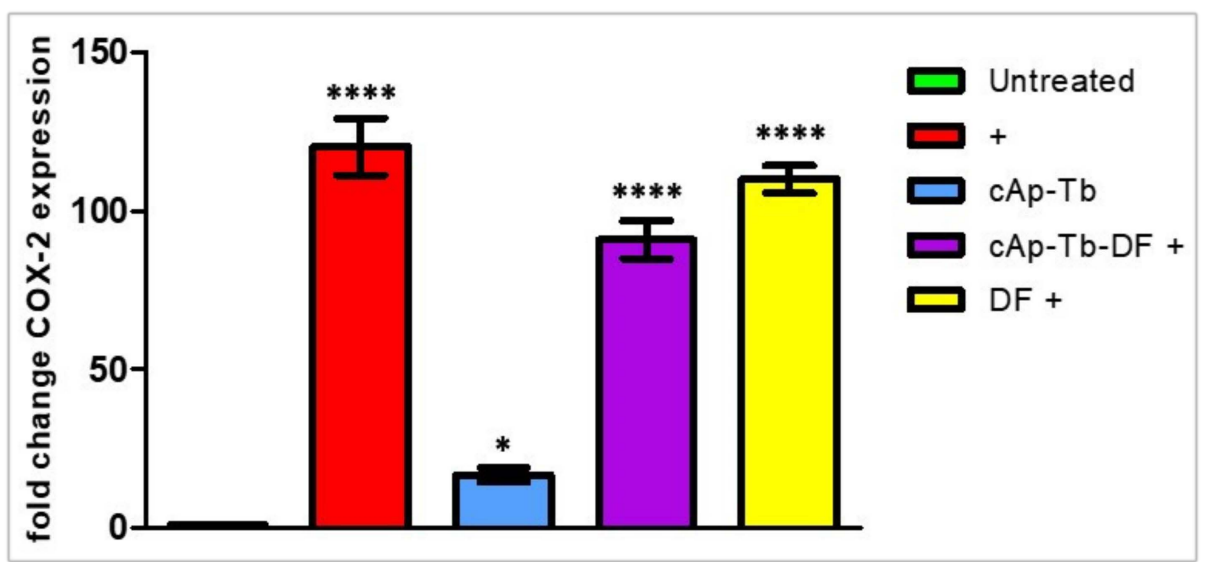

Figure 12. Effect of inflammation stimuli, $c A p-T b$ and soluble DF or cAp-Tb-DF, on COX-2 mRNA levels were assayed on hOB differentiated from mesenchymal stem cells. Cells were incubated for $24 \mathrm{~h}$ in presence or absence of the inflammatory stimuli. Data were calculated by comparing the fold increase vs. the untreated control and significance is shown on the figure. Bonferroni comparison post-test analysis of each treatment was calculated vs. the inflammation stimuli effects (marked as + ). Data indicated that DF and cAp-Tb-DF did not significantly modify the expression pattern induced by inflammation. Data represent means $\pm \mathrm{SD}$ of four independent experiments $\left({ }^{*} p<0.01\right.$, ***** $p<0.0005)$.

\subsection{DF-Loaded Nanoparticles Inhibit the Release of $P G E_{2}$ from Osteoblasts Treated for Inflammation}

The concentration of PGE2 in the culture medium was measured on days 1 and 5 using a PGE metabolite assay kit, which converts all major $\mathrm{PGE}_{2}$ metabolites in a single stable derivative, thus making more reliable the evaluation of $\mathrm{PGE}_{2}$ production. The amount of $50 \mu \mathrm{g} / \mathrm{mL}$ NPs was chosen for these experiments, since $100 \mu \mathrm{g} / \mathrm{mL}$ decreased cell viability, although not significantly. This amount was the best compromise for loading a significant amount of DF, and in the meantime it was fully cytocompatible. PGE 2 was constitutively released from hOB induced from mesenchymal stem cells at a measurable level (Figure 13: $50 \pm 10 \mathrm{pg} / \mathrm{mL})$, which was increased 9 fold $(450 \pm 64 \mathrm{pg} / \mathrm{mL}) 1$ day after the inflammation treatment. The addition of $\mathrm{cAp}$-Tb-DF to osteoblasts treated for inflammantion reduced the amount of the released $\mathrm{PGE}_{2}$ to about $4 \%(25 \pm 5 \mathrm{pg} / \mathrm{mL})$ of the amount released upon the inflammatory treatment, at levels even below the amount of the basally produced PGE2. cAp-Tb NPs did not show a significant inhibitory effect ( $435 \pm 35 \mathrm{pg} / \mathrm{mL})$, while soluble $\mathrm{DF}$ at comparable concentrations reduced $\mathrm{PGE}_{2}$ release at about the same levels observed for DF loaded on NPs $(16 \pm 4 \mathrm{pg} / \mathrm{mL})$. Thus, DF treatment reduced of $>95 \%$ the amount of PGE2 released 1 day after the inflammatory treatment.

When the levels of the released $\mathrm{PGE}_{2}$ were measured after 5 day treatments, similar results were observed, although all the values were increased. In this case the amount of constitutively released $\mathrm{PGE}_{2}$ was $135 \pm 15 \mathrm{pg} / \mathrm{mL}$, which was increased about 5 times by the inflammatory treatment $(680 \pm 35 \mathrm{pg} / \mathrm{mL})$, reaching even higher levels than those observed after 1 day. Coincubation with cAp-Tb-DF, as well as with soluble DF, resulted in a significant inhibition of cytokine-induced PGE2 production (110 \pm 12 and $87 \pm 25$, respectively), with a reduction around $85 \%$. 


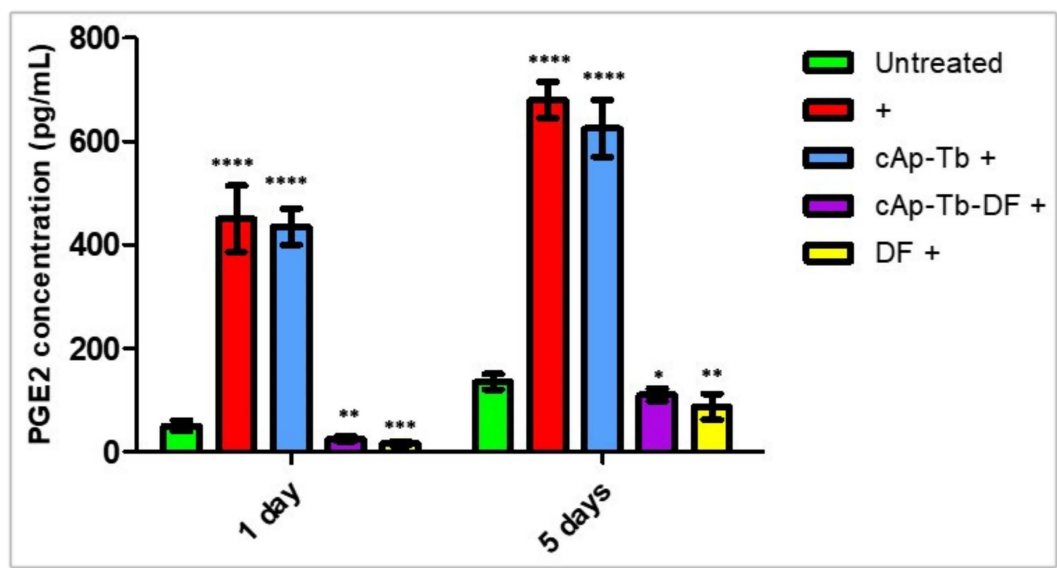

Figure 13. Effect of cAp-Tb-DF NPs on PGE2 released from differentiated hOBs treated with inflammatory cytokine mixture (IL- $1 \beta, \mathrm{TNF}-\alpha, \mathrm{IFN}-\gamma ;+)$. After 2 days, the different cAp $(50 \mu \mathrm{g} / \mathrm{mL})$ or DF (at comparable amount) were added and cells were incubated for further 1 day or 5 days. (see MM section for details). Data represent means $\pm \mathrm{sd}$ of three independent experiments performed in triplicate and statistical analyses were carried on using One-way ANOVA, with Bonferroni comparison test. For statistical analysis all data were compared to control untreated samples and the effect of DF was determined vs. the inflammatory treatment. Statistical significance $\left({ }^{*} p<0.01,{ }^{* *} p<0.005\right.$, $\left.{ }^{* * *} p<0.001,{ }^{* * * *} p<0.0005\right)$.

\section{Discussion}

cAp NPs are efficient tools for delivering biologically active molecules that might find applications in theranostics, especially in the field of oncology [59,60]. Herein we have prepared cAp and cAp-Tb nanoparticles and investigated their loading/release ability of DF, a potent non-steroidal antiinflammatory drug, using both nanocarriers in different conditions, and we have analyzed their cytocompatibility as well as their biological activities in an in vitro human osteoblast inflammation model. Indeed, today bone tissue pathologies, such as osteoporosis, osteoarthritis, rheumatoid arthritis represent important health problems with considerable socio-economic burden, linked to the general population aging $[8,9]$ and are all characterized by a clinical condition of inflammation.

As a result of the study, we have determined that cAp and cAp-Tb NPs -DF adsorption isotherms follow the Langmuir-Freundlich model at the two temperatures analysed of $25^{\circ} \mathrm{C}$ and $37^{\circ} \mathrm{C}$. Our data indicates that the adsorption is heterogeneous and takes place in multilayers, with a finite thickness. The $K_{L F}$ constants at $25^{\circ} \mathrm{C}$ are higher than at $37^{\circ} \mathrm{C}$, for both NPs, thus showing a higher affinity of the DF molecules for the adsorbent at room temperature. Moreover, at $25^{\circ} \mathrm{C}$ the adsorption is cooperative $(r>1)$ indicating that the binding of one molecule facilitates the adsorption of the next one, and that two or more molecules can even be adsorbed together. On the contrary, at $37^{\circ} \mathrm{C}$ the adsorption is non-cooperative, indicating that the adsorption of one molecule is not facilitated by the adsorption of the previous one. The maximum adsorbed amounts $Q_{\max }$, however, are greater at $37^{\circ} \mathrm{C}$, although they do not exceed the $0.063 \mathrm{mg} / \mathrm{mg}$ adsorbed on $\mathrm{cAp}$ - $\mathrm{Tb}$ for an initial DF concentration in the solution of $0.45 \mathrm{mg} / \mathrm{mL}$. The influence of the temperature on the adsorption processes, in general, is well documented [51]. Adsorption is an exothermic phenomenon, and thus an increase in temperature leads to a decrease in the adsorption capacity, which results in a lower $K_{L F}$, but, at the same time, it favours the solvate-solvate interaction so that the outermost layers attract a greater number of molecules.

Adsorption is influenced also by the $\mathrm{pH}$, especially when the adsorbents are ionic salts, since it determines their surface speciation, i.e., the concentration of cationic, anionic and neutral surface species (in apatite the species $>\mathrm{Ca}^{\delta+}$ and $>\mathrm{PO}_{\mathrm{x}}{ }^{\delta-}$ ) and, therefore, the net surface charge and the value and sign of the $\zeta$-potential of NP colloidal suspensions. In this work the adsorption experiments were carried out on NPs coated with citrate at $\mathrm{pH}$ 7.4. At this $\mathrm{pH}$, the $\zeta$-potentials of $\mathrm{cAp}$ and $\mathrm{cAp}$ - $\mathrm{Tb}$ nanoparticle suspensions are 
$\sim-5 \mathrm{mV}$ and $\sim 20 \mathrm{mV}$, respectively (Figure 3), indicating that in both cases the surface is negatively charged. The net negative charge is due to the citrate, which is a tricarboxylic acid, whose $\mathrm{pKs}$ are $\mathrm{pK}_{1}=3.128, \mathrm{pK}_{2}=4.761$, and $\mathrm{pK}_{3}=6.396$. At $\mathrm{pH} 7.4$, citrate would be electrostatically adsorbed on the apatite surface with one or two carboxylates $\left(-\mathrm{COO}^{-}\right)$, leaving the third deprotonated carboxylate exposed towards the solution [48]. In cAp$\mathrm{Tb}$, some of the surface species would be $>\mathrm{Tb}^{\delta+}$ atoms, which would mediate a slightly stronger electrostatic adsorption of citrate, resulting in more negatively charged nanoparticle (more negative $\zeta$-potential). After adsorbing DF at pH $7.4\left(25^{\circ} \mathrm{C}\right)$, either at $0.3 \mathrm{mg} / \mathrm{mL}$ $\left(Q_{\text {ads }}=0.02304 \mathrm{mg} / \mathrm{mg}\right)$, or at $0.45 \mathrm{mg} / \mathrm{mL}\left(Q_{\mathrm{ads}}=0.04246 \mathrm{mg} / \mathrm{mg}\right)$ concentrations, both cAp suspensions are stable ( $\zeta$-potential very different from 0$)$, although in different $\mathrm{pH}$ intervals, as shown in the graphs of $\zeta$-potential versus $\mathrm{pH}$ (Figure $3 \mathrm{a}$ ). In the first case, this is in the range $7<\mathrm{pH} \leq 9$ and to a lesser extent in the interval $4<\mathrm{pH}<7$, while in the second it is in the interval $6<\mathrm{pH} \leq 8$ and to a lesser extent in $4<\mathrm{pH} \leq 6$. Comparing the $\zeta$-potential at $\mathrm{pH} 7$, before and after the adsorption of $\mathrm{DF}$, the values went from $-5.0 \mathrm{mV}$, to $-6.9 \mathrm{mV}$ in the first case and to $-12.5 \mathrm{mV}$ in the second one. A possible explanation is that the adsorption of $\mathrm{Na}^{+}$and $\mathrm{H}^{+}$on the freely exposed $-\mathrm{COO}^{-}$groups of citrates, which partially neutralizes the negative charge, is followed by the adsorption of DF molecules through the dichloro phenyl ring, leaving the acetate group of the second phenyl exposed toward the solution, whose number would increase for cAp-DF loaded at $0.45 \mathrm{mg} / \mathrm{mL}$ $\left(Q_{\text {ads }}=0.04246 \mathrm{mg} / \mathrm{mg}\right)$. The multilayer could be produced by $\pi-\pi$ interaction between aromatic rings of different DF molecules. In the case of cAp-Tb-DF loaded with the $0.3 \mathrm{mg} / \mathrm{mL}$ DF solution (Figure $3 \mathrm{~b}, \mathrm{Q}_{\mathrm{ads}}=0.02680 \mathrm{mg} / \mathrm{mg}$ ), the suspension is quite stable in the range $6<\mathrm{pH} \leq 8$, and unstable at $\mathrm{pHs}$ lower and higher than these, since the $\zeta$-potential is around 0 . The suspension of cAp-Tb-DF particles loaded with the $0.45 \mathrm{mg} / \mathrm{mL}$ solution $\left(\mathrm{Q}_{\text {ads }}=0.04435 \mathrm{mg} / \mathrm{mg}\right)$ shows a slight stability in the range $5 \leq \mathrm{pH} \leq 7$, and instability at lower and higher $\mathrm{pHs}$, with $\zeta$-potential values close to 0 (Figure $3 \mathrm{~b}$ ). Comparing at $\mathrm{pH} 7$, the values went from $-19.0 \mathrm{mV}$ for the unloaded particles to $-10.6 \mathrm{mV}$ and -2.05 , for the DF-loaded ones, respectively. The presence of $>\mathrm{Tb}^{\delta+}$ atoms on the surface of $\mathrm{cAp}-\mathrm{Tb}$ nanoparticles influenced both citrate and DF binding differently to what observed for the cAp nanoparticles. Thus, DF showed almost similar affinity for the citrate-coated nanoparticles (similar $K_{L F}$ value), but a lower $r$ value, and outermost DF layers were less negatively charged.

Concerning the release trials, a slightly higher amount of drug was found to be released at acidic $\mathrm{pH}$ and at $37^{\circ} \mathrm{C}$. This can be explained on the following basis. Since the medium is acidic $(\mathrm{pH}=5.2)$ and $\mathrm{DF}$ is a weak acid ( $\mathrm{pKa}=3.99)$, its non-ionized form is still abundant and this favours the release of the molecules from the outermost layers in this medium, which would be more loosely linked.

Comparing the results of this work with those of the adsorption of a chemotherapeutic drug (doxorubicin) on cAp previously performed [50], we observed that at $37^{\circ} \mathrm{C}$ the $K_{L F}$ values for $\mathrm{DF}\left(K_{L F} \mathrm{cAp}=0.0572\right.$ and $\left.\mathrm{K}_{\mathrm{LF}} \mathrm{cAp}-\mathrm{Tb}=0.651\right)$ are lower than for doxorubicin $\left(K_{L F} \mathrm{CAp}=8\right)$. This indicates that doxorubicin is more strongly attracted to apatite than $\mathrm{DF}$, since the molecule is positively charged and interacts electrostatically with the free carboxylates of the citrate molecules.

Other studies of DF adsorption have been reported in the literature. In particular, DF was adsorbed on activated carbon at $\mathrm{pH} 4$ at $80^{\circ} \mathrm{C}$, and in this case the adsorption followed the Langmuir model [61], and on bentonite at neutral $\mathrm{pH}$ and temperatures from 10 to $77^{\circ} \mathrm{C}$ [62]. Nanocarriers of different composition have also been studied for the delivery of DF for biomedical applications, such as polysaccharides [63], poly( $\varepsilon$ caprolactone) micelles [64,65], magnetic NPs [66]. Concerning the adsorption of DF on any form of apatite as adsorbent, it was recently reported the adsorption on amino hydroxyapatite/chitosan/glutaraldehyde hybrids composites at $\mathrm{pH} 6$ [67], and the release of DF from injectable CaP-loaded systems to treat inflammation [68], but these authors did not study the adsorption isotherms, nor used luminescent apatites, therefore we cannot compare our results. In line with what we reported here (see beyond), in all these cases the 
compositions showed an anti-inflammatory activity on inflammation in vitro and in vivo experimental models.

In this work, $\mathrm{Tb}^{3+}$ was incorporated to provide the nanocarrier with a luminescence signal which can be measured to determine where the particles are located for imaging applications [29,55]. The excitation and emission spectra of NPs dispersed in aqueous media at pH 5.2 or pH 7.4 and at different temperatures $\left(25,37\right.$ and $\left.40{ }^{\circ} \mathrm{C}\right)$ were similar. In view of possible biological applications of the system the optimum $\lambda_{\text {exc }}$ and $\lambda_{\text {em }}$ of solid particles suggested are $350 \mathrm{~nm}$ and $545 \mathrm{~nm}$, respectively. The luminescence results of the cAp-Tb-DF conjugated nanoparticles show that R.L.I. is higher at pH 5.2 than at $\mathrm{pH} 7.4$, and the luminescence lifetime higher at $\mathrm{pH} 7.4$ than at 5.2, and that neither the concentration of DF nor the temperature affect the R.L.I. and the luminescence lifetime significantly. Thus, this signal cannot be used to determine if DF is released or not. On the other side, the luminescence emission of these particles could be used to determine $\mathrm{pH}$-changes, which are associated to the inflammatory processes. These NPs could be used in the context of inflammation, where local increases of temperature are observed, also because luminescence emission of these NPs does not change between 25 and $40{ }^{\circ} \mathrm{C}$.

When tested on cells, all NPs displayed high cytocompatibility on two human osteosarcoma cell lines after 3 day incubation. These NPs were cytocompabible after 7 days of incubation also on human osteoblasts, both primary, which were obtained from explants of human trabecular bone fragments, and differentiated with an appropriate protocol from human mesenchymal stem cells. These data are in line with previous ones, reporting the properties of other lanthanide-doped nanocrystals $[27,69]$. The absence of toxicity after long incubation time allowed us to do experiments lasting up to 5 days to assess the effects of the DF loaded on Tb-doped NPs. NPs loaded with the highest amounts of DF $(0.45 \mathrm{mg} / \mathrm{mg}$ $\mathrm{NP})$ released enough soluble DF $(0.046 \mathrm{mg} / \mathrm{mg} \mathrm{NP})$ to promote an anti-inflammatory effect in osteoblasts. We adopted a model where a cytokine mixture induced a significant inflammatory response in these cells monitored by the quantification of the cellular release of $\mathrm{PGE}_{2}$, an important inflammatory mediator produced after COX-2 enzyme activation [70]. To confirm that these nanoparticles do not interfere with the transcription of this enzyme, we performed quantitative real time PCR for determining COX-2 mRNA levels. Our data show that these nanocarriers do not influence cell metabolism at a transcription level. These data were also confirmed by the high levels of COX-2 mRNA expression observed after the treatment with DF-loaded cAp-Tb or soluble DF in the inflammation cell model which were comparable to the levels observed for the inflammation stimuli treatment. Thus, the significant reduction in the $\mathrm{PG} 2{ }_{2}$ release that we observed after the treatment of the inflamed cells with DF loaded cAp-Tb could be attributed specifically to the ability of cAp-Tb to release DF.

These results show the potential of cAp nanoparticles as nanocarriers for loading and controlled release of $\mathrm{DF}$, and of $\mathrm{cAp}-\mathrm{Tb}$ nanoparticles as luminescent nanoprobes with diagnostic, as well as therapeutic (theranostic) applications in pathological conditions.

\section{Conclusions}

We have studied the loading/release ability of DF on biomimetic cAp and cAp-Tb. The adsorption of the drug in both apatites has shown that, both at $25^{\circ} \mathrm{C}$ and at $37{ }^{\circ} \mathrm{C}$, follows the Langmuir-Freundlich model, giving rise to the formation of multilayers. The $K_{L F}$ constants at $25^{\circ} \mathrm{C}\left(K_{L F} \mathrm{cAp}=2.77\right.$ and $\left.K_{L F} \mathrm{cAp}-\mathrm{Tb}=2.98\right)$ are greater than at $37{ }^{\circ} \mathrm{C}$ $\left(K_{L F} \mathrm{cAp}=0.0572\right.$, and $\left.K_{L F} \mathrm{cAp}-\mathrm{Tb}=0.651\right)$, reflecting a higher affinity for the molecules by the nanoparticles at $25^{\circ} \mathrm{C}$, and in particular towards cAp-Tb. Furthermore, in both cases the adsorption is cooperative.

The release of DF from the nanoparticles is favoured when it occurs at an acidic $\mathrm{pH}$ (5.2) and at a temperature of $37^{\circ} \mathrm{C}$, releasing $2 \%$ more of the drug than in a neutral medium. This data is relevant since the aim of this study is to be able to use biomimetic nanoparticles loaded with DF in pathological conditions, in bone trauma and fractures, in which prolonged inflammatory processes occur with a local increase in temperature and a decrease 
in the $\mathrm{pH}$ of the medium. The luminescence results of the $\mathrm{cAp}-\mathrm{Tb}-\mathrm{DF}$ conjugated nanoparticles show that R.L.I. is higher at $\mathrm{pH} 5.2$ than at $\mathrm{pH}$ 7.4, and the luminescence lifetime higher at $\mathrm{pH} 7.4$ than at 5.2, and that neither the concentration of DF nor the temperature affect the R.L.I. and the luminescence lifetime significantly. Luminescence emission of these particles could have biological applications in inflammation, since it can detect $\mathrm{pH}$ changes, not being affected by the raise of temperature, being both conditions associated with the inflammatory process. Concerning cell behaviour, all the nanocarriers studied showed no reduction in osteoblasts cell vitality and in an in vitro model of osteoblasts cytokine-induced inflammation, they affected COX-2 expression and decreased the cellular production of prostaglandin $E_{2}$. These results show the potential of cAp nanoparticles as nanocarriers for loading and controlled release of $\mathrm{DF}$, and of $\mathrm{cAp}-\mathrm{Tb}$ nanoparticles as luminescent nanoprobes with diagnostic, as well as therapeutic (theranostic) applications in pathological conditions.

Supplementary Materials: The following figures are available online at https:/ /www.mdpi.com/ article/10.3390/nano12030562/s1. Figure S1: X-ray diffraction patterns of cAp and cAp-Tb prepared by thermal decomplexing method, Figure S2: (a) FTIR and (b) Raman spectra of cAp and cAp-Tb prepared by thermal decomplexing method, Figure S3: (a) PSD in volume and (b) cumulative oversize PSD of cAp and cAp-Tb. Figure S4: Evolution of the adsorbed amount of DF with time on cAp (a) and $\mathrm{cAp}-\mathrm{Tb}$ (b). Figure S5: Excitation (dashed lines) and emission (solid lines) uncorrected spectra of samples containing different $\mathrm{DF}$ concentrations dispersed in a $\mathrm{pH}=5.2$ aqueous suspension at $0.5 \mathrm{mg} / \mathrm{mL}$ and $25^{\circ} \mathrm{C}$. Figure S6: Excitation (dashed lines) and emission (solid lines) uncorrected spectra of samples containing different $\mathrm{DF}$ concentrations dispersed in a $\mathrm{pH}=5.2$ aqueous suspension at $0.5 \mathrm{mg} / \mathrm{mL}$ and $40{ }^{\circ} \mathrm{C}$. Figure S7: Excitation (dashed lines) and emission (solid lines) uncorrected spectra of samples containing different $\mathrm{DF}$ concentrations dispersed in a $\mathrm{pH}=7.4$ aqueous suspension at $0.5 \mathrm{mg} / \mathrm{mL}$ and $25^{\circ} \mathrm{C}$. Figure S8: Excitation (dashed lines) and emission (solid lines) uncorrected spectra of samples containing different $\mathrm{DF}$ concentrations dispersed in a $\mathrm{pH}=7.4$ aqueous suspension at $0.5 \mathrm{mg} / \mathrm{mL}$ and $37^{\circ} \mathrm{C}$. Figure S9: Excitation (dashed lines) and emission (solid lines) uncorrected spectra of samples containing different $\mathrm{DF}$ concentrations dispersed in a $\mathrm{pH}=7.4$ aqueous suspension at $0.5 \mathrm{mg} / \mathrm{mL}$ and $40{ }^{\circ} \mathrm{C}$. Figure S10: Luminescence decay curves at different DF concentrations of $0.5 \mathrm{mg} / \mathrm{mL}$ suspended particles at $25^{\circ} \mathrm{C}$ and pH 5.2. $\lambda_{\text {exc } / \mathrm{em}}=350 / 545 \mathrm{~nm}$, $\mathrm{t}_{\mathrm{d}}=120 \mu \mathrm{s}, \mathrm{t}_{\mathrm{g}}=0.01 \mathrm{~ms}$, slitwidth $\mathrm{exc}_{\mathrm{em}}=20 / 20 \mathrm{~nm}$ and detector voltage $900 \mathrm{v}$. Figure S11: Luminescence decay curves at different DF concentrations of $0.5 \mathrm{mg} / \mathrm{mL}$ suspended particles at $37^{\circ} \mathrm{C}$ and pH 5.2. $\lambda_{\text {exc } / \mathrm{em}}=350 / 545 \mathrm{~nm}, \mathrm{t}_{\mathrm{d}}=120 \mu \mathrm{s}, \mathrm{t}_{\mathrm{g}}=0.01 \mathrm{~ms}$, slitwidth $\mathrm{exc}_{\mathrm{em}}=20 / 20 \mathrm{~nm}$ and detector voltage $900 \mathrm{v}$. Figure S12: Luminescence decay curves at different DF concentrations of $0.5 \mathrm{mg} / \mathrm{mL}$ suspended particles at $40^{\circ} \mathrm{C}$ and $\mathrm{pH} 5.2 . \lambda_{\text {exc } / \mathrm{em}}=350 / 545 \mathrm{~nm}, \mathrm{t}_{\mathrm{d}}=120 \mu \mathrm{s}, \mathrm{t}_{\mathrm{g}}=0.01 \mathrm{~ms}$, slitwidth $_{\text {exc } / \mathrm{em}}=20 / 20 \mathrm{~nm}$ and detector voltage $900 \mathrm{v}$. Figure S13: Luminescence decay curves at different DF concentrations of $0.5 \mathrm{mg} / \mathrm{mL}$ suspended particles at $25^{\circ} \mathrm{C}$ and pH 7.4. $\lambda_{\text {exc }} / \mathrm{em}=350 / 545 \mathrm{~nm}$, $\mathrm{t}_{\mathrm{d}}=120 \mu \mathrm{s}, \mathrm{t}_{\mathrm{g}}=0.01 \mathrm{~ms}$, slitwidth $\mathrm{exc}_{\mathrm{em}}=20 / 20 \mathrm{~nm}$ and detector voltage $900 \mathrm{v}$. Figure S14: Luminescence decay curves at different $\mathrm{DF}$ concentrations of $0.5 \mathrm{mg} / \mathrm{mL}$ suspended particles at $37^{\circ} \mathrm{C}$ and pH 7.4. $\lambda_{\text {exc } / \mathrm{em}}=350 / 545 \mathrm{~nm}, \mathrm{t}_{\mathrm{d}}=120 \mu \mathrm{s}, \mathrm{t}_{\mathrm{g}}=0.01 \mathrm{~ms}$, slitwidth $_{\text {exc } / \mathrm{em}}=20 / 20 \mathrm{~nm}$ and detector voltage $900 \mathrm{v}$. Figure S15: Luminescence decay curves at different DF concentrations of $0.5 \mathrm{mg} / \mathrm{mL}$ suspended particles at $40^{\circ} \mathrm{C}$ and $\mathrm{pH} 7.4 . \lambda_{\text {exc }} / \mathrm{em}=350 / 545 \mathrm{~nm}, \mathrm{t}_{\mathrm{d}}=120 \mu \mathrm{s}, \mathrm{t}_{\mathrm{g}}=0.01 \mathrm{~ms}$, slitwidth $_{\text {exc } / \mathrm{em}}=20 / 20 \mathrm{~nm}$ and detector voltage $900 \mathrm{v}$. Figure S16: Viability of MG-63 cells (a) and of U-2OS cells (b) incubated with cApTb-DF particles loaded with different DF concentration, ranging from 0.1 to $0.45 \mathrm{mg} / \mathrm{mg} \mathrm{NP}$, for three days. Figure S17: Osteoblasts differentiated from human mesenchymal stem cells express alkaline phosphatase.

Author Contributions: Conceptualization, J.G.-M., D.C.-L., D.C. and M.P.; methodology, S.M.C.P., A.D., J.F.F.-S., R.F. and M.B.; investigation, S.M.C.P., J.G.-M., J.F.F.-S., M.P., A.D. and D.C.; supervision, J.G.-M. and M.P.; writing — original draft preparation, M.P. and J.G.-M.; writing—review and editing, M.P., J.G.-M., D.C. and J.F.F.-S.; funding acquisition, J.G.-M., D.C.-L. and M.P. All authors have read and agreed to the published version of the manuscript.

Funding: This research was funded by Spanish Agencia Estatal de Investigación (AEI) of the Ministerio de Ciencia e Innovación (MCI) and co-funded with FEDER, UE, Project No. PGC2018-102047-B-I00 (MCIU/AEI/FEDER, UE). M.P. acknowledges the Progetto di Ricerca Fondi di Ateneo per la Ricerca- 
FAR 2018 “Development of innovative biological materials for the functional regeneration of cardiac tissue models".

Data Availability Statement: Not applicable.

Conflicts of Interest: The authors declare no conflict of interest.

\section{References}

1. Etter, E.L.; Mei, K.-C.; Nguyen, J. Delivering More for Less: Nanosized, Minimal-Carrier and Pharmacoactive Drug Delivery Systems. Adv. Drug Deliv. Rev. 2021, 179, 113994. [CrossRef] [PubMed]

2. Dutta, B.; Barick, K.C.; Hassan, P.A. Recent Advances in Active Targeting of Nanomaterials for Anticancer Drug Delivery. Adv. Colloid Interface Sci. 2021, 296, 102509. [CrossRef] [PubMed]

3. Subramaniam, S.; Joyce, P.; Thomas, N.; Prestidge, C.A. Bioinspired Drug Delivery Strategies for Repurposing Conventional Antibiotics against Intracellular Infections. Adv. Drug Deliv. Rev. 2021, 177, 113948. [CrossRef] [PubMed]

4. Jelinkova, P.; Mazumdar, A.; Sur, V.P.; Kociova, S.; Dolezelikova, K.; Jimenez, A.M.J.; Koudelkova, Z.; Mishra, P.K.; Smerkova, K.; Heger, Z.; et al. Nanoparticle-Drug Conjugates Treating Bacterial Infections. J. Control. Release 2019, 307, 166-185. [CrossRef]

5. Macedo, L.D.O.; Barbosa, E.J.; Löbenberg, R.; Bou-Chacra, N.A. Anti-Inflammatory Drug Nanocrystals: State of Art and Regulatory Perspective. Eur. J. Pharm. Sci. 2021, 158, 105654. [CrossRef]

6. Wong, C.Y.; Al-Salami, H.; Dass, C.R. Potential of Insulin Nanoparticle Formulations for Oral Delivery and Diabetes Treatment. J. Control. Release 2017, 264, 247-275. [CrossRef]

7. Ozawa, T.; Yoshimura, H.; Kim, S.B. Advances in Fluorescence and Bioluminescence Imaging. Anal. Chem. 2013, 85, 590-609. [CrossRef]

8. Clynes, M.A.; Harvey, N.C.; Curtis, E.M.; Fuggle, N.R.; Dennison, E.M.; Cooper, C. The Epidemiology of Osteoporosis. Br. Med. Bull. 2020, 133, 105-117. [CrossRef]

9. Salari, N.; Ghasemi, H.; Mohammadi, L.; Behzadi, M.H.; Rabieenia, E.; Shohaimi, S.; Mohammadi, M. The Global Prevalence of Osteoporosis in the World: A Comprehensive Systematic Review and Meta-Analysis. J. Orthop. Surg. Res. 2021, 16, 609. [CrossRef]

10. Curtis, E.M.; Moon, R.J.; Dennison, E.M.; Harvey, N.C.; Cooper, C. Recent Advances in the Pathogenesis and Treatment of Osteoporosis. Clin. Med. 2016, 16, 360-364. [CrossRef]

11. Grässel, S.; Zaucke, F.; Madry, H. Osteoarthritis: Novel Molecular Mechanisms Increase Our Understanding of the Disease Pathology. J. Clin. Med. 2021, 10, 1938. [CrossRef]

12. Ain, Q.; Zeeshan, M.; Khan, S.; Ali, H. Biomimetic Hydroxyapatite as Potential Polymeric Nanocarrier for the Treatment of Rheumatoid Arthritis. J. Biomed. Mater. Res. Part A 2019, 107, 2595-2600. [CrossRef]

13. Gomez-Morales, J.; Iafisco, M.; Delgado-López, J.M.; Sarda, S.; Drouet, C. Progress on the preparation of nanocrystalline apatites and surface characterization: Overview of fundamental and applied aspects. Prog. Cryst. Growth Charact. Mater. 2013, 59, 1-46. [CrossRef]

14. Hu, Y.Y.; Rawal, A.; Schmidt-Rohr, K. Strongly bound citrate stabilizes the apatite nanocrystals in bone. Proc. Natl. Acad. Sci. USA 2010, 107, 22425-224259. [CrossRef]

15. Low, K.L.; Tan, S.H.; Zein, S.H.S.; Roether, J.A.; Mouriño, V.; Boccaccini, A.R. Calcium Phosphate-Based Composites as Injectable Bone Substitute Materials: A Review. J. Biomed. Mater. Res. Part B Appl. Biomater. 2010, 94B, 273-286. [CrossRef]

16. Ding, Z.Z.; Fan, Z.H.; Huang, X.W.; Bai, S.M.; Song, D.W.; Lu, Q.; Kaplan, D.L. Bioactive Natural Protein-Hydroxyapatite Nanocarriers for Optimizing Osteogenic Differentiation of Mesenchymal Stem Cells. J. Mater. Chem. B 2016, 4, $3555-3561$. [CrossRef]

17. Gera, S.; Sampathi, S.; Dodoala, S. Role of Nanoparticles in Drug Delivery and Regenerative Therapy for Bone Diseases. Curr. Drug Deliv. 2017, 14, 904-916. [CrossRef]

18. Pietrzykowska, E.; Romelczyk-Baishya, B.; Chodara, A.; Koltsov, I.; Smogór, H.; Mizeracki, J.; Pakieła, Z.; Łojkowski, W. Microstructure and Mechanical Properties of Inverse Nanocomposite Made from Polylactide and Hydroxyapatite Nanoparticles. Materials 2022, 15, 184. [CrossRef]

19. Bystrova, A.; Dekhtyar, Y.D.; Popov, A.; Coutinho, J.; Bystrov, V. Modified hydroxyapatite structure and properties: Modeling and synchrotron data analysis of modified hydroxyapatite structure. Ferroelectrics 2015, 475, 135-147. [CrossRef]

20. Munir, M.U.; Salman, S.; Javed, I.; Bukhari, S.N.A.; Ahmad, N.; Shad, N.A.; Aziz, F. Nano-Hydroxyapatite as a Delivery System: Overview and Advancements. Artif. Cells Nanomed. Biotechnol. 2021, 49, 717-727. [CrossRef]

21. Tram Do, T.N.; Lee, W.-H.; Loo, C.-Y.; Zavgorodniy, A.V.; Rohanizadeh, R. Hydroxyapatite Nanoparticles as Vectors for Gene Delivery. Ther. Deliv. 2012, 3, 623-632. [CrossRef]

22. Zhang, Y.; Zhang, L.; Ban, Q.; Li, J.; Li, C.-H.; Guan, Y.-Q. Preparation and Characterization of Hydroxyapatite Nanoparticles Carrying Insulin and Gallic Acid for Insulin Oral Delivery. Nanomed. Nanotechnol. Biol. Med. 2018, 14, 353-364. [CrossRef]

23. Iafisco, M.; Delgado-Lopez, J.M.; Varoni, E.M.; Tampieri, A.; Rimondini, L.; Gomez-Morales, J.; Prat, M. Cell Surface Receptor Targeted Biomimetic Apatite Nanocrystals for Cancer Therapy. Small 2013, 9, 3834-3844. [CrossRef]

24. Khalifehzadeh, R.; Arami, H. Biodegradable Calcium Phosphate Nanoparticles for Cancer Therapy. Adv. Colloid Interface Sci. 2020, 279, 102157. [CrossRef] 
25. Oltolina, F.; Gregoletto, L.; Colangelo, D.; Gómez-Morales, J.; Delgado-López, J.M.; Prat, M. Monoclonal Antibody-Targeted Fluorescein-5-Isothiocyanate-Labeled Biomimetic Nanoapatites: A Promising Fluorescent Probe for Imaging Applications. Langmuir 2015, 31, 1766-1775. [CrossRef]

26. Chen, M.-H.; Yoshioka, T.; Ikoma, T.; Hanagata, N.; Lin, F.-H.; Tanaka, J. Photoluminescence and Doping Mechanism of Theranostic $\mathrm{Eu}^{3+} / \mathrm{Fe}^{3+}$ Dual-Doped Hydroxyapatite Nanoparticles. Sci. Technol. Adv. Mater. 2014, 15, 055005. [CrossRef]

27. Gómez-Morales, J.; Fernández-Penas, R.; Romero-Castillo, I.; Verdugo-Escamilla, C.; Choquesillo-Lazarte, D.; D’Urso, A.; Prat, M.; Fernández-Sánchez, J.F. Crystallization, Luminescence and Cytocompatibility of Hexagonal Calcium Doped Terbium Phosphate Hydrate Nanoparticles. Nanomaterials 2021, 11, 322. [CrossRef]

28. Haque, S.T.; Islam, R.A.; Gan, S.H.; Chowdhury, E.H. Characterization and Evaluation of Bone-Derived Nanoparticles as a Novel pH-Responsive Carrier for Delivery of Doxorubicin into Breast Cancer Cells. Int. J. Mol. Sci. 2020, 21, 6721. [CrossRef]

29. Delgado-López, J.M.; Iafisco, M.; Rodríguez, I.; Tampieri, A.; Prat, M.; Gómez-Morales, J. Crystallization of Bioinspired CitrateFunctionalized Nanoapatite with Tailored Carbonate Content. Acta Biomater. 2012, 8, 3491-3499. [CrossRef]

30. Jabalera, Y.; Oltolina, F.; Prat, M.; Jimenez-Lopez, C.; Fernández-Sánchez, J.F.; Choquesillo-Lazarte, D.; Gómez-Morales, J. Eu-doped citrate-coated carbonated apatite luminescent nanoprobes for drug delivery. Nanomaterials 2020, 10, 199. [CrossRef] [PubMed]

31. Shang, H.-B.; Chen, F.; Wu, J.; Qi, C.; Lu, B.-Q.; Chen, X.; Zhu, Y.-J. Multifunctional biodegradable terbium-doped calcium phosphate nanoparticles: Facile preparation, $\mathrm{pH}$-sensitive drug release and in vitro bioimaging. RSC Adv. 2014, 4, 53122-53129. [CrossRef]

32. Wang, Y.; Lu, Y.; Zhang, J.; Hu, X.; Yang, Z.; Guo, Y.; Wang, Y. A synergistic antibacterial effect between terbium ions and reduced graphene oxide in a poly(vinyl alcohol)-alginate hydrogel for treating infected chronic wounds. J. Mater. Chem. B 2019, 7, 538-547. [CrossRef]

33. Liu, D.D.; Ge, K.; Jin, Y.; Sun, J.; Wang, S.X.; Yang, M.S.; Zhang, J.C. Terbium promotes adhesion and osteogenic differentiation of mesenchymal stem cells via activation of the Smad-dependent TGF- $\beta$ /BMP signaling pathway. J. Biol. Inorg. Chem. 2014, 19, 879-891. [CrossRef] [PubMed]

34. Romero-Castillo, I.; López-Ruiz, E.; Fernández-Sánchez, J.F.; Marchal, J.A.; Gómez-Morales, J. Self-Assembled Type I CollagenApatite Fibers with Varying Mineralization Extent and Luminescent Terbium Promote Osteogenic Differentiation of Mesenchymal Stem Cells. Macromol. Biosci. 2021, 21, 2000319. [CrossRef]

35. Gan, T.J. Diclofenac: An Update on Its Mechanism of Action and Safety Profile. Curr. Med. Res. Opin. 2010, 26, 1715-1731. [CrossRef]

36. Rojas, A.; Chen, D.; Ganesh, T.; Varvel, N.H.; Dingledine, R. The COX-2/Prostanoid Signaling Cascades in Seizure Disorders. Expert Opin. Ther. Targets 2019, 23, 1-13. [CrossRef]

37. Rainsford, K.D. Profile and Mechanisms of Gastrointestinal and Other Side Effects of Nonsteroidal Anti-Inflammatory Drugs (NSAIDs). Am. J. Med. 1999, 107, 27-35. [CrossRef]

38. Kołodziejska, J.; Kołodziejczyk, M. Diclofenac in the Treatment of Pain in Patients with Rheumatic Diseases. Rheumatology 2018, 56, 174-183. [CrossRef]

39. Gouda, A.A.; Kotb El-Sayed, M.I.; Amin, A.S.; el Sheikh, R. Spectrophotometric and Spectrofluorometric Methods for the Determination of Non-Steroidal Anti-Inflammatory Drugs: A Review. Arab. J. Chem. 2013, 6, 145-163. [CrossRef]

40. Bosetti, M.; Leigheb, M.; Brooks, R.A.; Boccafoschi, F.; Cannas, M.F. Regulation of Osteoblast and Osteoclast Functions by FGF-6. J. Cell. Physiol. 2010, 225, 466-471. [CrossRef]

41. Roato, I.; Belisario, D.C.; Compagno, M.; Verderio, L.; Sighinolfi, A.; Mussano, F.; Genova, T.; Veneziano, F.; Pertici, G.; Perale, G.; et al. Adipose-Derived Stromal Vascular Fraction/Xenohybrid Bone Scaffold: An Alternative Source for Bone Regeneration. Stem Cells Int. 2018, 2018, 4126379. [CrossRef]

42. Zamperone, A.; Pietronave, S.; Merlin, S.; Colangelo, D.; Ranaldo, G.; Medico, E.; di Scipio, F.; Berta, G.N.; Follenzi, A.; Prat, M. Isolation and Characterization of a Spontaneously Immortalized Multipotent Mesenchymal Cell Line Derived from Mouse Subcutaneous Adipose Tissue. Stem Cells Dev. 2013, 22, 2873-2884. [CrossRef]

43. Sidney, L.E.; Heathman, T.R.; Britchford, E.R.; Abed, A.; Rahman, C.V.; Buttery, L.D. Investigation of localized delivery of diclofenac sodium from poly(D,L-lactic acid-co-glycolic acid)/poly(ethylene glycol) scaffolds using an in vitro osteoblast inflammation model. Tissue Eng. Part A 2015, 21, 362-373. [CrossRef]

44. Fornai, M.; Blandizzi, C.; Colucci, R.; Antonioli, L.; Bernardini, N.; Segnani, C.; Baragatti, B.; Barogi, S.; Berti, P.; Spisni, R.; et al. Role of Cyclooxygenases 1 and 2 in the Modulation of Neuromuscular Functions in the Distal Colon of Humans and Mice. Gut 2005, 54, 608-616. [CrossRef]

45. Ramírez-Rodríguez, G.B.; Delgado-López, J.M.; Gómez-Morales, J. Evolution of Calcium Phosphate Precipitation in Hanging Drop Vapor Diffusion by in Situ Raman Microspectroscopy. CrystEngComm 2013, 15, 2206. [CrossRef]

46. Langmuir, I. The Adsorption of Gases on Plane Surfaces of Glass, Mica and Platinum. J. Am. Chem. Soc. 1918, 40, 1361-1403. [CrossRef]

47. Adamson, A.W. Physical Chemistry of Surfaces; Wiley: New York, NY, USA, 1997.

48. López-Macipe, A.; Gómez-Morales, J.; Rodríguez-Clemente, R. The Role of pH in the Adsorption of Citrate Ions on Hydroxyapatite. J. Colloid Interface Sci. 1998, 200, 114-120. [CrossRef] 
49. Reed, B.E.; Matsumoto, M.R. Modeling Cadmium Adsorption by Activated Carbon Using the Langmuir and Freundlich Isotherm Expressions. Sep. Sci. Technol. 1993, 28, 2179-2195. [CrossRef]

50. Rodríguez-Ruiz, I.; Delgado-López, J.M.; Durán-Olivencia, M.A.; Iafisco, M.; Tampieri, A.; Colangelo, D.; Prat, M.; GómezMorales, J. pH-Responsive Delivery of Doxorubicin from Citrate-Apatite Nanocrystals with Tailored Carbonate Content. Langmuir 2013, 29, 8213-8221. [CrossRef]

51. Azizian, S.; Eris, S. Adsorption Isotherms and Kinetics. In Interface Science and Technology; Academic Press: London, UK, 2021; Volume 33, pp. 445-509. [CrossRef]

52. Hemmilä, I.; Dakubu, S.; Mukkala, V.-M.; Siitari, H.; Lövgren, T. Europium as a Label in Time-Resolved Immunofluorometric Assays. Anal. Biochem. 1984, 137, 335-343. [CrossRef]

53. Lakowicz, J.R. Principles of Fluorescence Spectroscopy; Springer: Boston, MA, USA, 2006. [CrossRef]

54. Kaur, A.; Dhakal, S. Recent Applications of FRET-Based Multiplexed Techniques. TrAC Trends Anal. Chem. 2020, $123,115777$. [CrossRef]

55. Hänninen, P.; Härmä, H. (Eds.) Lanthanide Luminescence Photophysical, Analytical and Biological Aspects; Springer: Berlin/Heidelberg, Germany, 2011. [CrossRef]

56. Medina-Velazquez, D.Y.; Caldiño, U.; Morales-Ramirez, A.; Reyes-Miranda, J.; Lopez, R.E.; Escudero, R.; Ruiz-Guerrero, R.; Morales Perez, M.F. Synthesis of Luminescent Terbium-Thenoyltriflouroacetone MOF Nanorods for Green Laser Application. Opt. Mater. 2019, 87, 3-10. [CrossRef]

57. Richardson, F.S. Terbium(III) and Europium(III) Ions as Luminescent Probes and Stains for Biomolecular Systems. Chem. Rev. 1982, 82, 541-552. [CrossRef]

58. ISO 10993-5; Biological Evaluation of Medical Devices Part 5: Tests for In Vitro Cytotoxicity. International Standard Organization: Geneve, Switzerland, 2009.

59. Fenton, O.S.; Olafson, K.N.; Pillai, P.S.; Mitchell, M.J.; Langer, R. Advances in Biomaterials for Drug Delivery. Adv. Mat. 2018, 30, e1705328. [CrossRef]

60. Van der Meel, R.; Sulheim, E.; Shi, Y.; Kiessling, F.; Mulder, W.J.M.; Lammers, T. Smart cancer nanomedicine. Nat. Nanotechnol. 2019, 14, 1007-1017. [CrossRef]

61. Larous, S.; Meniai, A.-H. Adsorption of Diclofenac from Aqueous Solution Using Activated Carbon Prepared from Olive Stones. Int. J. Hydrog. Energy 2016, 41, 10380-10390. [CrossRef]

62. Abbas, A.M.B.; Muhseen, R.J. Adsorption of Diclofenac Sodium and Ibuprofen by Bentonite Polyureaformaldehyde Thermodynamics and Kinetics Study. Iraqi J. Chem. Pet. Eng. 2018, 19, 29-43.

63. Cohen, Y.; Rutenberg, R.; Cohen, G.; Veltman, B.; Gvirtz, R.; Fallik, E.; Danino, D.; Eltzov, E.; Poverenov, E. Aminated Polysaccharide-Based Nanoassemblies as Stable Biocompatible Vehicles Enabling Crossing of Biological Barriers: An Effective Transdermal Delivery of Diclofenac Medicine. ACS Appl. Bio Mater. 2020, 3, 2209-2217. [CrossRef]

64. Arias, J.L.; López-Viota, M.; Sáez-Fernández, E.; Ruiz, M.A. Formulation and Physicochemical Characterization of Poly( $\varepsilon$ Caprolactone) Nanoparticles Loaded with Ftorafur and Diclofenac Sodium. Colloids Surf. B Biointerfaces 2010, 75, 204-208. [CrossRef]

65. Al-Lawati, H.; Vakili, M.R.; Lavasanifar, A.; Ahmed, S.; Jamali, F. Reduced Heart Exposure of Diclofenac by Its Polymeric Micellar Formulation Normalizes CYP-Mediated Metabolism of Arachidonic Acid Imbalance in an Adjuvant Arthritis Rat Model: Implications in Reduced Cardiovascular Side Effects of Diclofenac by Nanodrug Delivery. Mol. Pharm. 2020, 17, 1377-1386. [CrossRef]

66. Agotegaray, M.; Palma, S.; Lassalle, V. Novel Chitosan Coated Magnetic Nanocarriers for the Targeted Diclofenac Delivery. J. Nanosci. Nanotechnol. 2014, 14, 3343-3347. [CrossRef]

67. Pereira, M.B.B.; França, D.B.; Araújo, R.C.; Silva Filho, E.C.; Rigaud, B.; Fonseca, M.G.; Jaber, M. Amino Hydroxyapatite/Chitosan Hybrids Reticulated with Glutaraldehyde at Different $\mathrm{PpH}$ Values and Their Use for Diclofenac Removal. Carbohydr. Polym. 2020, 236, 116036. [CrossRef]

68. Fasolino, I.; Soriente, A.; Ambrosio, L.; Grazia Raucci, M. Osteogenic and Anti-Inflammatory Behavior of Injectable Calcium Phosphate Loaded with Therapeutic Drugs. Nanomaterials 2020, 10, 1743. [CrossRef]

69. Gómez-Morales, J.; Verdugo-Escamilla, C.; Fernández-Penas, R.; Parra-Milla, C.M.; Drouet, C.; Iafisco, M.; Oltolina, F.; Prat, M.; Fernández-Sánchez, J.F. Bioinspired Crystallization, Sensitized Luminescence and Cytocompatibility of Citrate-Functionalized Ca-Substituted Europium Phosphate Monohydrate Nanophosphors. J. Colloid Interface Sci. 2019, 538, 174-186. [CrossRef]

70. Hughes, F.J.; Buttery, L.D.K.; Hukkanen, M.V.J.; O’Donnell, A.; Maclouf, J.; Polak, J.M. Cytokine-Induced Prostaglandin E2 Synthesis and Cyclooxygenase-2 Activity Are Regulated Both by a Nitric Oxide-Dependent and -Independent Mechanism in Rat Osteoblasts in Vitro. J. Biol. Chem. 1999, 274, 1776-1782. [CrossRef] 